LSA Project

Task Report

5101-54, VOL. II
DOE/JPL/1012-78/1

Distribution Category UC-63

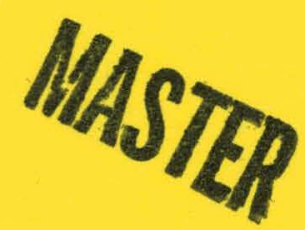

\title{
Historical Evidence of Importance to the Industrialization of Flat-Plate Silicon Photovoltaic Systems
}

Prepared for

Department of Energy

by

Jet Propulsion Laboratory

California Institute of Technology

Pasadena, California

(JPL PUBLICATION 78-36) 


\section{DISCLAIMER}

This report was prepared as an account of work sponsored by an agency of the United States Government. Neither the United States Government nor any agency Thereof, nor any of their employees, makes any warranty, express or implied, or assumes any legal liability or responsibility for the accuracy, completeness, or usefulness of any information, apparatus, product, or process disclosed, or represents that its use would not infringe privately owned rights. Reference herein to any specific commercial product, process, or service by trade name, trademark, manufacturer, or otherwise does not necessarily constitute or imply its endorsement, recommendation, or favoring by the United States Government or any agency thereof. The views and opinions of authors expressed herein do not necessarily state or reflect those of the United States Government or any agency thereof. 


\section{DISCLAIMER}

Portions of this document may be illegible in electronic image products. Images are produced from the best available original document. 
Prepared by the Jet Propulsion Laboratory, California Institute of Technology, for the Department of Energy by agreement with the National Aeronautics and Space Administration.

The JPL Low-Cost Solar Array Project is sponsored by the Department of Energy (DOE) and forms part of the Solar Photovoltaic Conversion Program to initiate a major effort toward the development of low-cost solar arrays.

This report was prepared as an account of work sponsored by the United States Government. Neither the United States nor the United States Department of Energy, nor any of their employees, nor any of their contractors, subcontractors, or their employees, makes any warranty, express or implied, or assumes any legal liability or responsibility for the accuracy, completeness or usefulness of any information, apparatus, product or process disclosed, or represents that its use would not infringe privately owned rights. 
LSA Project

DOE/JPL-1012-78/1

Task Report

Distribution Category UC-63

5101-54, VOL. II

\title{
Historical Evidence of Importance to the Industrialization of Flat-Plate Silicon Photovoltaic Systems
}

\author{
Jeffrey L. Smith \\ William R. Gates \\ Tom Lee
}

April 1978

Prepared lor

Department of Energy

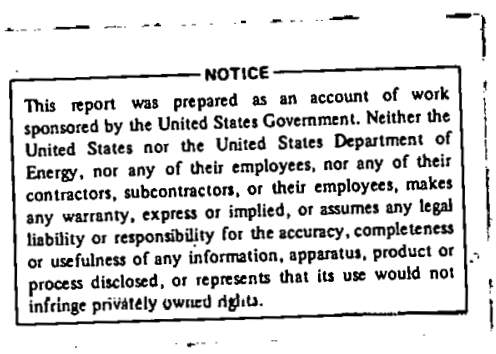

by

Jet Propulsion Laboratory

California Institute of Technology

Pasadena, California

(JPL PUBLICÁTION 78-36) 
THIS PAGE

\section{WAS INTENTIONALLY LEFT BLANK}


PREFACE

This paper is one of a continuing series of economic analyses conducted by the Project Analysis and Integration Task of the Low Cost Silicon Solar Array Project of the National Photovoltaic Conversion Program. The intent of these studies is to anticipate problems which may arise as the Project pursues its objectives of lowering the production cost of photovoltaic arrays to a level competitive with other sources of electricity, and to insure a smooth transition from government $R, D \& D$ to private commercial production.

The study' is concerned with two somewhat disjoint subjects - the diffusion of new industrial production processes and the determinants of success of previous federally funded demonstration projects. The research was limited to secondary sources. In essence, a literature search on these two subjects was the primary aim of the study.

That search led, however, to some fairly strong conclusions out of which specific recommendations for the future plans and conduct of the LSSA project have been derived. It must be emphasized that these recommendations are made only on the basis of the evidence.considered. That is, no attempt has been made to incorporate the myriad other factors which bear significantly on the Project (e.g., funding levels or political imperatives). Thus, these recommendations are not a comprehensive set of project management recommendations to the Photovoltaic Program of the Department of Encrgy. They are to be vicwed as an input into such a comprehensive set. 
The guidance and direction for this and other studies in the series has been supplied by Dr. James Doane. Separately issued background papers, upon which this study draws heavily, have been prepared. These papers, "Prospects for Innovation and Diffusion of Photovoltaic Technology" by Bill Gates, and "Sequential PilotDemonstration-Commercial Strategy and Its Relation to LSSA's Industrialization Plans" by Tom Lee, form the basis for Sections II and III, respectively. A heavy debt is owed to each member of the study team.

Special thanks are due to Beverly Williams for her efforts, above and beyond the call of duty, to ensure that each of the many drafts of this paper were promptly typed and processed. 
I. INTRODUCTION - $1-1$
A. PURPOSE
B. RESPONSIBILITY ---
C. MOTIVATION -
D. ORGANIZATION - 1-4

II. INDUSTRIAL STIMULATION -

A. INTRODUCTION -

B. PRODUCT PRICE -- 2-2

C. MARKET DEMAND - $2-3$

D. INNOVATION, DIFFUSION AND COMPETITION ----_----------- 2-4

1. Information-Flow Inhibitors -- 2-7

2. Capital Availability --_-_-_- 2-9

3. Market Structure - 2-12

4. Governmental Barriers --_-17

E. CASE STUDIES -- 2-19

1. Semiconductors -- 2-19

2. Petroleum Refining --- 2-26

3. Iron and Steel - 2-27

F. SUMMARY -

G. OUTPUT TARGET --_- 2-30

III. THE CONCORDE SYNDROME

A. INTRODUCTION -- 3-1

B. LSSA PLANS - 3-3

C. DEFINITIONS AND PURPOSES --

D. .. PILOT PLANTS - 3-7

E. DEMONSTRATIONS AND COMMERCIAL PRODUCTION --_-_ 3-12

1. Commercial Production - 3-18

2. Summary - 3-21

IV. SUMMARY AND CONCLUSIONS --

BIBLIOGRAPHY - 


\section{TABLES}

2-1. Major Product Innovations in the Semiconductor

Industry, 1951-68----------

2-2. Major Process Innovations in the Semiconductor

Industry, 1950-68--

2-3. Dates of Conception, Reduction to Practice, and First

Publication for Major Semiconductor Innovations Achieved

by Bell Laboratories, 1947-68--

3-1. Technological Uncertainty vs. Project Success- 3-9

3-2. Time Constraints vs. Pro.ject Success -- 3-13

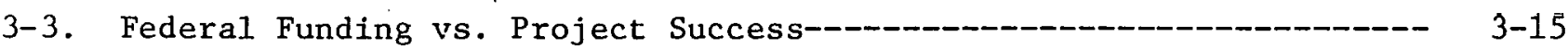

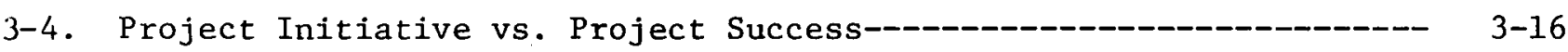

3-5. Strength of TDS vs. Project Success-- 3-19

3-6. TDS Components vs. Project Success-_ 3-20 


\section{SECTION I}

INTRODUCTION

\section{A. PURPOSE}

This report is intended to define, elucidate, and comment on problems which may arise as the Low Cost Silicon Solar Array (LSSA) Project attempts to industrialize (as opposed to commercialize) the new production technologies expected to be forthcoming as a result of the Technology Development efforts of the project. In particular, LSSA's charge to insure an annual production capability of 500 MW peak for the photovoltaic supply industry by 1986 is critically examined. The examination focuses on one of the motivations behind this goal-concern over the timely development of industrial capacity to supply anticipated demand. Conclusions from the analysis are then utilized in a discussion of LSSA's industrialization plans, particularly the plans for pilot, demonstration and commercial scale production plants. Specific recommendations for the implementation of an industrialization task and the disposition of the project quantity goal are derived.

\section{B. RESPONSIBILITY}

For the purposes of the National Photovoltaic Program (and this paper) industrialization has been explicitly defined as the process by which new technology is adopted by the photovoltaic supply industry. Commercialization, on the other hand, refers to the process by which an effective demand for photovoltaics is realized, given product price. Thus, commercialization deals with user acceptance and industrialization with supplier acceptance. The photovoltaic program currently allocates the analysis of industrialization issues to JPL's Project Analysis and Integration Task (PA\&I), while the problems associated with commercialization are the responsibility of other parts of the program.*

\footnotetext{
* See Commercialization and Industrialization of Photovoltaics: Draft Plan,
} Photovoltaic Program Planning Group, July 1977. 
The PA\&I task has been charged with five specific activities, among which are:

(1) Assess the goals and progress of the LSSA project and

(2) Contribute to the generation and development of Project plans ${ }^{1}$.

Since much of the previous effort of the PA\&I task has focused on issues surrounding the LSSA price goal of $50 \mathrm{c} /$ peak watt by 1986 , this paper concentrates on the second goal--the annual output capacity of $500 \mathrm{MW}$ peak.

\section{MOTIVATION}

The activities of the Photovoltaic Conversion Program of. DOE's Division of Solar Technology are planned "to develop and to promote the use of photovoltaic systems to such an extent that the private sector will produce and utilize costcompetitive photovoltaic systems"L (italics added). This broad statement of purpose has been translated into specific objectives for both the photovoltaic program and the LSSA project. In particular, the specific JPL project goal for 1985-86 is "to reduce today's (1975) solar array prices of $\$ 20,000$ to $\$ 25,000$ per kilowatt (peak) in annual quantities of 100 kilowatts to less than $\$ 500$ per kilowatt (peak) in annual quantities of 500,000 kilowatts."13

Given the emphasis on cost-competitiveness and private sector production with which the program began, the importance attached to price reduction seems entirely appropriate. Most of LSSA's resources are devoted to reducing the cost of photovoltaic arrays, and as pointed out above, the primary efforts of the PA\&I Task have been directed at analyses concerning the price goal. . It is clear that photovoltaics will never make a significant contribution to the nation's energy supply unless and until it becomes competitive, in the price dimension, with other sources of electricity.

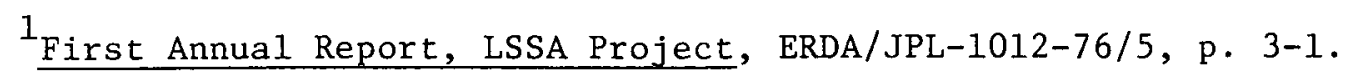

2 Ibid, p. 1-1

3 Ibid, p. 1-1. 
However, from the beginning both the program and project have been concerned that a demonstration of the technical ability to produce solar arrays at a "cost-effective" price will not be sufficient to bring about their speedy introduction, acceptance, and diffusion into the energy production sector. Thus, the cost reduction goal has been supplemented with other goals specifically aimed at promoting user and supplier acceptance.*

"The objectives of the ERDA [DOE] Program are:

...To stimulate the creation of a viable industrial and commercial capability to produce and distribute these systems for widespread use in commercial, residential, and governmental applications."

"JPL's role in the ERDA [DOE] plan:

To encourage expansion of industrial capability to produce solar arrays. To support methods of user acceptance."

It seems clear that the $500 \mathrm{MW}$ peak/year output goal of the LSSA Project is partially, if not wholly, the result of such concerns over supplier acceptance of new technology.

However, there are at least two possible interpretations of, or motivations for, the 500 MW peak/year output in addition to the promotion of supplier acceptance. First, attainment of the output gual has come to be viewed as an aid in the successful realization of the project price goal. That is, through the operation of the learning curve, assuring a large annual output will in and of itself promote the attainment of a smaller per unit cost.

More fundamentally, the $500 \mathrm{MW}$ peak/year goal can be interpreted as an ultimate standard against which the entire photovoltaic program may be judged. Since $500 \mathrm{MW}$ is approximately one percent of the total annual additions to the electrical generation capacity in the United States, this may be viewed as the threshold level above which the photovoltaic program will be considered a success. The implications for the LSSA project of either alternative interpretation of the output goal are elaborated below.

\footnotetext{
* Ibid, p. 1-1.
} 
Thus, this report analyzes the industrialization goal of the LSSA project. The conclusions of that analysis are used to develop recommendations with respect to pilot, demonstration and commercial scale production plants, as well as the disposition of the current LSSA annual output goal.

\section{ORGANIZATION}

Section II begins the analysis with an examination of the likelihood that significant barriers to the wide-spread adoption of new photovoltaic production techniques will exist given that: the project has successfully attained a product price of $50 \mathrm{c} /$ peak watt and user acceptance has been successfully promoted. Specifically, the probability that barriers arising from (1) industry structure (2) capital availability or (3) inadequate information transfer may significantly impede the adoption of new production techniques by the photovoltaic supply industry is examined. The key roles played by the dual assumptions of an effective market demand (user acceptance) at a cost-competitive price are emphasized.

Our general conclusion is that the likelihood of significant delay, given effective demand for the product, is quite small. That is, given that users desire the product at $50 \mathrm{c} /$ peak watt (commercialization is successful) and that the capability exists to profitably manufacture them for this price, it is extremely unlikely that production will not quickly be forthcoming, even without any significant government aid or prodding. Our best guess, supported by considerable evidence (see text), is that 1-2 years is a reasonable estimate of the lag from the moment such conditions exist until the new process is commercially producing and filling market demands. Thus, we expect no barriers to the adoption of new technology from the supply side.

In light of this conclusion, the LSSA project goals and plans are re-evaluated. First, recommendations for the disposition of the $500 \mathrm{MW}$ peak/ year output goal are developed. Then, a third chapter begins an examination of the LSSA plans for pilot, demonstration and commercial scale production plants. An intensive and wide-ranging analysis of previous federal demonstration programs is included to isolate those factors which have contributed to their success or failure. 
A final chapter presents a summary and our recommendations and conclusions, among which are:

(1) Construction of small scale pilot plants is recommended if and when it is believed they would significantly contribute to technology development.

(2) Large-scale demonstrations of photovoltaic production technology should only be undertaken when, from the operating experience gained in pilot facilities, it is determined that the technology is "well-in-hand."

(3) Commercial scale production of photovoltaic arrays should be left to the private sector. (However, significant quantities of arrays will likely be forthcoming from the demonstration in (2) above. Furthermore, an adequate demonstration may be physicaliy identical to expected future commercial plants.)

(4) The $500 \mathrm{MW} /$ peak annual output goal should be shifted to Program Headquarters if it is meant as a passive standard against which to judge the success of the entire photovoltaic program (one percent of the total net additions to electrical generating capacity in the U.S.).* Other interpretations of the purpose of this output goal lead to the conclusion that its level should not be predetermined. Rather, it should be set as deemed necessary for demonstrations, tests, etc.

hOF luusse, LSSA Is currently a major portion of the Photovoltaics Program and as such remains committed to Program goals, including any production capacity goals. The eluse cunlacl belween JPL and the photovoltaic array industry gives JPL a unique advantage for the accomplishment of certain tasks necessary to implement a capacity goal. In particular, the monitoring of current industry production techniques and quantities, industry views of future government and private markets, and industry willingness to invest in new technologies can probably best be accomplished within the LSSA Project. 
SECTION II

INDUSTRIAL STIMULATION

\section{A. INTRODUCTION}

As pointed out above, the LSSA project has been charged with the attainment of two distinct goals--both price and quantity of output targets. The $500 \cdot \mathrm{MW}$ peak/year quantity goal fiows directly from the often expressed desire to stimulate industrial adoption of innovative production techniques. Thus, JPL is instructed to "encourage expansion of industrial capability to produce solar arrays."* This concern over the future development of photovoltaic supply appears throughout the National Photovoltaic Program. For example, the federal Photovoltaic Utilization Act currently before Congress is designed to, among other things, "accelerate the growth of a commercially viable photovoltaic industry."

Furthermore, these statements are always coupled to a proviso that the resultant photovoltaic industry be self-sustaining, competitive and private. Thus, a government owned or government sustained industry appears to be ruled out. The supply target arises from a concern that significant barriers may exist to the development of an efficient supply industry and the belief that these barriers will yield to government prodding. Specifically, there is concern over the rapidity with which new production techniques will be adopted by or introduced into the photovoltaic industry, and with their subsequent diffusion throughout the industry. In essence, the call for industrial stimulation is a call for government lubrication of the transfer of new solar cell production techniques to private industry.

This section is intended to examine the basis for these concerns and determine whether the anticipated barriers are real or ephemeral. Although product price (and thus profitability) and product demand are identified as real and paramount concerns, they do not provide a legitimate basis upon which to support industry stimulation. No other significant barriers (other than price and demand) to the rapid introduction and diffusion of supply technology are anticipated, although several possibilities are discussed. This conclusion is

\footnotetext{
*First Annual Report, LSSA Project, p. 1-1.
} 
supported by evidence on 18 major product and process innovations in the semiconductor industry, an industry quite similar to the photovoltaic industry, as well as other empirical studies. Thus, we conclude that efforts at industrial stimulation, as distinct from efforts to produce information (R\&D) or encourage market demand (commercialization), are unnecessary.

\section{B. PRODUCT PRICE}

The major effort of the Photovoltaic Program is directed at reducing the price of arrays to a level competitive with other sources of electricity generation. The 1986 price of $50 \mathrm{c} /$ peak watt is one of a number of sequential price targets established by the Program office. It is clear that attainment of a competitive price is absolutely essential to the development of a significant photovoltaic industry.

However, the complexity involved in the realization of this goal is considerable. Much more than a simple laboratory verification of a 50 c/peak watt production price is required. A tremendous amount of information must be generated along several dimensions of uncertainty before the price goal is, in fact, accomplished. It is not enough to demonstrate a process with the possibility of attaining a particular price per unit. The probability of attainment must be high enough such that the risks are considered acceptable by private markets. Thus, uncertainties with respect to reliability, externalities, and regulation must all be lowered to acceptable levels. The several stages of $R, D \& D$ are designed to attack specific types of uncertainty through the generation of new information (see Section III for an elaboration of this sequence). All of these activities, aimed at the production of new information, are properly classified as parts of the effort to increase the likelihood of actual array production and sale at a specific output price.

Only if sufficient information is generated in each dimension will photovoltaic supply firms be reasonably:confident that they can produce arrays profitably at this price.

This section, however, is concerned with a second and distinct activity of the LSSA project--supply industry stimulation. Thus, although the pre-eminence of attaining the price goal is recognized and its importance acknowledged, it is 
assumed for the moment that this part of the project will be successful. That is, we assume the price goal will be attained, with the implication that if an efficiently managed plant can find a market for its product at $50 \mathrm{c} /$ peak watt, then it will be able to operate profitably.

\section{MARKET DEMAND}

This raises a second crucial issue upon which the success of photovoltaics depends--market demand. Even if it is clearly shown that arrays can be profitably produced at $50 \mathrm{c} /$ peak watt, it is of equal importance to show that a significant demand for the arrays will exist at this price. ${ }^{1}$

Unless it can be shown that attainment of the price goal will provide the possibility of reducing the cost of energy in a significant number of applications (that is, that photovoltaics'is "cost-effective" to electricity suppliers and users), there will be no place to sell the newly produced arrays. Thus, the estimation of future prices of alternative sources of electricity is imperative, and drives the importance attached to any particular LSSA price target. Further, it must be shown that this potential demand for photovoltaics will become effective--that buyers will find out about and appear in the photovoltaics market place: ${ }^{2}$

${ }^{1}$ Sep Sertion TIT for two examples of previous federal R,D\&D Programs which successfully attained their price targets, but ultimately failed because sufficient market demand did not materialize (Fish Protein Concentrate and Desalination at Freeport, Texas).

2 The diffusion of photovoltaic arrays into the electricity supply sector is a separate and distinct issue from the diffusion of new production processes for photovoltaics into the photovoltaic supply industry. Given that dispersed residential and agricultural applications are currently envisioned to become a large fraction of the photovoltaic applications market, a priori reasoning would suggest diffusion of the final product will be a much more important "problem" than diffusion of the new processes currently being developed to produce that product, since the number of individuals who must make decisions to adopt is much greater in the former case. Furthermore, most of the existing sociological, geographical and economic literature has dealt with diffusion of final products to dispersed buyers such as consumers and farmers. The literature dealing with industrial process diffusion is considerably more limited. It is the latter with which this section is concerned, however. 
The issues related to market demand and its realization--alternative energy prices, estimates of potential markets, diffusion of photovoltaic arrays, demonstrations of photovoltaic installations, etc.--fall into the category dubbed "commercialization" issues which currently are not under the purview of the LSSA project. Thus, even though the importance of these issues is acknowledged; we move directly to the problem at hand by assuming an effective market demand for photovoltaics will arise when the price target is successfully realized.

To many, including ourselves, these dual assumptions of (1) successfully meeting the price goal and (2) realizing an effective market demand, robs the analysis of its most important issues. However, it allows a finer.focus on a third potentially dangerous barrier to the successful completion of the Photovoltaic Program, namely, barriers on the supply side to the adoption of new production technologies. The following sections proceed with a discussion of several such potential barriers which often arise in discussions of supply side issues.

\section{INNOVATION, DIFFUSION AND COMPETITION}

Given that a product price of 50 / / peak watt has been established and that an effective market demand has been realized, the photovoltaic industry must still adopt the technology, produce and sell arrays at this price. The length of time between the establishment of a technology's viability and the first commercial adoption of that technology (innovation) is of considerable interest. The rate at which the technology spreads to other photovoltaic suppliers (diffusion) is also quite important. Together, they refer to a process of ten called "technology transfer." It is clear that there must be some lag between the establishment of commercial viability and innovation, due to the physical necessity of planning and constructing new production lines. Evidence is presented below which indicates that less than a year is necessary to bring such a facility on line.* Further, the optimal rate of diffusion is clearly not

*This assumes sufficient floor space can be made available without the construction of any buildings. The construction of new buildings would add 12 to 18 months to the time necessary for production capacity to be brought on line. The P,A\&I Task Cost Goal Allocation Team has estimated that approximately $1800 \mathrm{sq}$. ft. of floor space will be required for each MW of annual output capacity. 
instantaneous if older production facilities exist which are still economically viable. Thus, estimates of the optimum rate of diffusion of photovoltaic production processes and the expected divergence between the actual and this optimum are required.

New capital utilizes variable inputs in a more efficient way than old capital, and thus has the advantage of lower operating costs. On the other hand, the cost of existing capital is sunk. Therefore, while current equipment has higher operating costs, it has no capital costs. William Salter writes, "...the cost of new capital equipment is the barrier to immediate general use of new techniques, and higher operating costs are the price paid for retaining outmoded methods."* Optimality from the firm's point of view requires that existing capital be replaced by capital embodying the current best practice technology as soon as the older capital becomes economically obsolete. In a competitive market, price will be bid down as soon as new, more efficient technology is incorporated into the production processes of some firms. As price decreases, the high operating costs of older capital equipment will no longer be fully recovered, at which point the old capital becomes economically obsolete. At this point, older capital wiil be scrapped and replaced by capital embodying the new technology. Net additions to the capital stock will. augment this process in a growing industry. Thus, through both replacement investment and net additions to the capital stock, the percentage of the industry's output using the new technology will gradually increase, and the invention will spread throughout the industry. Neither the socially or privately optimal rates of diffusion, however, yield an initial complete adoption of a new technology. Furthermore, the two rates will generally be identical in a competitive market with no significant externalities.

*William E: Salter, Productivity and Technological Change (Cambridge, England: Cambridge Univ. Press, 1966). 
Edwin Mansfield presents some interesting empirical observations on the diffusion of innovations in the bituminous coal, iron and steel, brewing, and railroad industries*:

First, the diffusion of a new technique is generally a rather slow process. Measuring from the date of the first successful application, it took 20 years or more for all the major firms to install centralized traffic control, car retarders, by-product coke ovens, and continuous annealing. Only in the case of the pallet loading machine, tin container, and continuous mining machine did it take 10 years or less for all the major firms to install them.

Second, the rate of imitation varies widely. Although it sometimes took decades for firms to install new techniques, in other caeae they'followad tho innovator quickly. For example, it took about 15 years for half of the major pigiron producers to use the by-product coke oven, but only about three years for half of the major coal producers to use the continuous mining machine. The number of years elapsing before half. the firms had introduced an innovation varied from 0.9 to 15 , the average being 7.8 .

Thus, diffusion rates can be slow and vary widely. Substantial evidence is presented below which supports an anticipation of quite rapid diffusion in the photovoltaic supply industry, however.

Further, a rapid diffusion of new technology is not essential to the success of the Photovoltaic Program, even though it is anticipated. In a competitive industry, price will be determined by the most efficient technology, given that some producers have adopted it. Thus, although it is critical that a portion of the industry adopt the technology, it is not necessary for the entire industry to convert before the full benefits to society from that new production technology are forthcoming.

Although still preliminary, current evidence suggests that the anticipated photovoltaic supply industry will be competitive. Other than governmental

\footnotetext{
*Edwin Mansfield, Industrial Research and Technological Innovation (New York: W. W. Norton \& Co., 1971). p. 136.
} 
restrictions on compatition (as in regulated utilities, for example) the most important determinant of the competitiveness of an industry is the optimum size firm in relation to the size of the market. If there is enough "room" in the market for a large number of firms of the optimum size to produce, then the industry will sell its output at the lowest possible price--the competitive price. The optimum size firm is determined, of course, by the shape of the average cost curve--a firm is an optimum size if it is producing at that rate of output where the cost per unit output is at its minimum.

Other members of the P,A\&I Task Team have developed sophisticated and detailed process-cost models of the anticipated photovoltaic technologies (called SAMICS models). These models can be used to generate average cost curves. Although development is still proceeding, it appears that these curves reach a minimum in the range of 20-50 MW peak/year. That is, all the economies of scale seem to be exhausted in a plant of this size. Since $50 \mathrm{MW}$ peak/year is substantially smaller than the envisioned photovoltaic market, there would seem to be plenty of room for competitors to profitably enter with an optimally scaled plant. Thus, the photovoltaic supply industry is expected to be quite competitive unless there are other barriers or impediments to entry into the market (other than market size).

- The next four sections discuss possible impediments to the rapid adoption or diffusion of the new technologies anticipated for the production of photovoltaics. These impediments have been classified as either information-flow inhibitors, capital shortages, market structure barriers or governmental barriers.

1. Information-Flow Inhibitors

Before a potential entrant or existing photovoltaic supplier can adopt a new technology, they must have access to and the ability to employ detailed information about that process. Barriers can arise because the firm simply remains ignorant of the process or from patents and proprietary information held by other firms.

The dissemination. of information, however, is viewed as more of a problem for the demand side of the industiy than fur lie supply side. Suppliers 
typically have well developed information channels and actively seek out new knowledge. In addition, as discussed below, the industry is expected to be characterized by a mobile labor force and to establish liberal licensing policies which will increase the flow of information within the industry. Furthermore, the pilot and demonstration plants included in the program plan will increase the amount of information available. Therefore, a simple lack of information is not expected to create significant barriers to the widespread dissemination of new technology within the photovoltaic supply industry.*

Patents or proprietary information are also not anticipated to create significant barriers to the adoption or diffusion of new photovoltaic technologies. Currently, government funded technologlcal developments are considered public property and are available on a non-exclusive basis. Therefore, patents should not restrict the dissemination of government produced knowledge. Furthernore, experience shows that the probability that new firms will use new technology without patent rights is surprisingly high. Therefore, firms in research intensive industries frequently adopt liberal licensing policies. The firm hopes to entice its competitors to purchase a lenient license, as opposed to simply ignoring the patent, as they might with more stringent license agreements. This policy has the added advantage of giving firms ready access to new ideas developed in other firms. This is particularly important in research-intensive industries, such as photovoltaics, where one firm cannot hope to make all the technological developments.

Scientists and engineers are likely. to be mobile because of the lucrative opportunities created by the possibility of establishing a new firm based on a new technological development. As a result of this mobility, and the desire of most scientists and engineers to publish, secrecy regarding new knowledge is hard to maintain.

\footnotetext{
*See "ISSA's Efforts Toward Effective Technology Transfer" a JPL unpublished memo, for a detailed discussion of the steps JPL takes to insure adequate information flow to industry.
} 
Each of these conditions have held in the semiconductor industry, a research-intensive industry quite similar to the anticipated photovoltaic industry (see below for a detailed comparison). Therefore, limitations to the widespread adoption of new technology due to barriers in the flow of knowledge between inventors and eventual users are not expected in the photovoltaic supply industry. (It is on the basis of these arguments that section III argues that photovoltaic supply demonstrations planned by the Photovoltaic Program be aimed primarily at information production, not.information transfer).

\section{Capital Availability}

Probably no supply side barrier is mentioned more often that the possibility that sufficient venture capital may not be forthcoming to adequately capitalize a new, untried industry or process. Of course, capital will not be forthcoming if there is not a reasonable expectation, with acceptable levels of risk, of making a profit. But given that a venture offers a reasonable profit opportunity, most analysts agree that sufficient capital is easily attainable.

Mansfield states the problem*:

The application of new technology...is often begun by smal1 businesses run by technical people with little business experience and little knowledge of the market for venture capital. On the other hand, the banks, wealthy individuals and others who are in a position to put up the money typically have no appreciation of technical matters (and their staffs are often of little use in this area, either). ... Without a question, an important determinant of the rate of application of new technology is the size of the pool of venture capital-and the efficiency and Imagination with which it is lent out.

Therefore, capital availability represents a potential impediment to the diffusion of technology. Shortages of capital can erect entry barriers for new firms who cannot rely on internally generated funds. If this is the case, government action is needed to increase the availability of venture capital.

*Edwin Mansfield, "Determinants of the Speed of Application of New Technology" in B.R. Williams, Science and Technology in Economic Growth (New York: John Wiley and Sons, 1973), p. 205. 
There are, however, good reasons to doubt that capital availability will create a significant barrier to the diffusion of photovoltaic supply technology. In the first place, entry into the photovoltaic supply industry is not limited to firms that are just beginning commercial operation. If current suppliers are slow to incorporate improvements in the production technology, then firms with existing operations in other product areas can also be expected to enter the industry. These firms will have established channels for obtaining funds, as well as internally generated capital. Therefore, capital market imperfections will create a possible problem only for a portion of the potential entrants-the newly established firms. Furthermore, evidence indicates that there has not been a shortage of venture capital. John Tilton states, in an insightful study of the semiconductor industry, "Venture cap1tal for new semiconductur lirms lids been readily available, at times even lavishly so."1 Carter and Williams point out that there are many channels through which the enterprising entrepreneur can acquire capital funds. They conclude, "A firm of any size but the largest may of course be held back because the next stage of technical improvement is too massive for its resources; but we do not think that this is a frequent problem in the kinds of specialists trades in which small firms flourish."2 Therefore, capital market imperfections should not impede the entry of new firms incorporating new production techniques into the photovoltaic supply industry.

However, progressive, rapidly expanding firms may be frustrated by capital constraints. As Tilton writes, "...capital apparently is more of a problem for the successful small company that wants to expand rapidly." ${ }^{3}$ This ma cause new firms that have successfully introduced a technological improvement to merge with a larger firm in order to obtain financial backing. But this will not impede the entry of these new firms into the photovoltaic supply industry.

${ }^{1}$ John E. Tilton, International Diffusion of Technology: The Case of Semiconductors, (Washington, D.C.: The Brookings Institution, 1971.), p. 89.

${ }^{2}$ C. F. Carter and B. R. Williams, Industry and Technical Progress, (London, Oxford University Press, 1957), p. 123.

${ }^{3}$ Tilton, International Diffusion, p. 88. 
The MIT Energy Laboratory Policy Study Group reached a similar conclusion on the availability of venture capital*:

It is often argued that investment in new energy-related technologies is blocked by lack of financing. The investments at the introduction stage are so risky, it is argued, that private investors are unwilling to advance the necessary capital.

Even if true, this may or may not be a "market failure." When an investment banker states, for example, that large-scale synthetic gas plants "can't be financed," he may simply mean that the expected profitability of investment in such a plant is not high enough to compensate for the risks that would have to be borne.

...Society as well should demand a high expected return on capital, the higher the associated risks.

...The U.S. has a highly elaborated and efficient set of capital. markets, and these offer extensive opportunities for spreading risks. The combination of markets for loan funds and the various stock markets for equity capital--. supplemented by. various forms of joint corporate ventures--can serve to diversify risks very widely over the community of stock and bond holders. These markets appear to serve very well in supporting potentially profitable investment--including very large and risky ones--in energy and other sectors of the economy.

... Not all corporate managers are risk averse: We observe corporations, for example, investing hundreds of millions

- to acquire off-shore drilling rights, even though there is a significant change (proven by experience) of getting nothing at all.

Thus, shortages of capital are not expected to cause significant delays in the wide-spread adoption of new photovoltaic conversion technologies.

*Policy Study Group, Energy Laboratory, Massachusetts Institute of Technology, Government Support for the Commercialization of New Energy Technologies, (Cambridge, Mass: Energy Laboratory Report MIT-EL 76-009, November 1976). 


\section{Market Structure}

Market structure refers to the number and distribution by size of the firms within an industry and the ease with which new firms can enter. As discussed above, preliminary indications are that a sizable photovoltaic supply industry will have enough room to support many efficiently sized firms. Thus, it is expected to be competitive. This will insure a product price close to the minimum production cost (including a competitive rate of return or profit), but may also have implications for the diffusion of new technologies. Furthermore, the plants are expected to be relatively small (50 MW peak/year oucput race), although they may be one production line of a much larger firm, possibly a major semi-conductor manufacturer. This section discusses, respectively, the effects of firm size, competition, flexible entry, and rapid technological change on innovation and diffusion.

a. Firm Size. The size of firm may affect the profitability of adopting a new production process. Large firms may have an advantage in their ability to locate and exploit information protected by patent or kept secret by other firms. On the other hand, large firms are sometimes thought to have sluggish, risk averse decision making processes which may reduce their propensity to innovate. In the smaller, typically owner-supervised firms, the propensity to innovate is dependent on the personality and ability of the owner. Therefore, an aggressive entrepreneur in a small firm may be able to overcome the advantages of the bigger, though less innovative larger firms. After weighing the differences in the size of the capital stock, level of output, and managerial capabilities of large versus small firms, it seems prudent to conclude that a diversily of firm bizes will enhance the rate of adoplion and diffusion of new production processes. Thus, as Carter and Williams state, "We conclude therefore--and this conclusion is confirmed by. our case studies--that there is no general and systematic connection between the size of firms ... and the possibility of technical 
progressiveness. This possibility exists at all sizes ... but each has its own balance of advantages and disadvantages whose outcome depends on the circumstances of the time and industry."*

b. Competition. There is a great deal of controversy concerning what industry structure (competitive vs. monopolistic) is most conducive to the spread of a new invention. On the one hand, adopting a new technology implies a great deal of risk, involves a large level of funding, and requires the ability to plan over a long time horizon. It is felt that the monopolist, because he-is isolated from the uncertainties of competition, is better able to incorporate these traits than is the competitive firm. In addition, the incentive to innovate is based on the profitability of the innovation. In a competitive industry, these profits will be eliminated more quiçkly than in a monopolistic industry. Therefore, a monopolist, because of his more secure market position, will have a greater incentive to innovate than a competitive firm. On the other hand, competition forces the competitor to actively seek out new technologies, and apply them as soon as it is profitable to do so. The monopolist is immune to this influence and therefore may delay before he introduces a new technique. (See, for example, the experience of the semiconductor industry vs. the iron and steel industry below). Though the debate is still unsettled, the latter influence is expected to dominate, and diffusion is generally assumed to proceed mure rapidly in a competitive industry.

c. Flexible Entry. The analysis of the effect of competition on the rate of innovation and diffusion assumes that the market structure is fixed, and that the rate of adoption of new ideas will depend on this exogenously determined form of organization. A more realistic approach is to assume that the structure of the industry will be in a continual state of flux. New technology creates; new products and production processes, establishes new markets, and gives rise to new firms and changing market shares. Therefore, industry structure is an evolutionary process. The crucial factor is to maintain low

*Carter and Wiliiams, Progress, p. 126. 
entry barriers and a flexible structure which can adjust to the continually changing conditions. Tilton stresses the importance of new firms in the diffusion process. He writes, "...the diffusion of new technology is stimulated by a flexible market structure that allows new firms to arise and replace the established industry leaders whenever the latter delay too long in using new techniques." 1 Empirical evidence indicates that the potential entry and growth of new firms provides one of the most powerful incentives for the rapid diffusion of new technology.

The importance of maintaining low entry barriers and a flexible market structure in order to stimulate the rate of adoption of new technology has been stressed by many authors. E. Roberts, for example, describes the role that the entrepreneur plays in the diffusion of new technology. He then goes on to state, "Although the on-going corporation is at least on occasion the active scene of technical entrepreneurship, it is in the new firm that the innovating entrepreneur flourishes." 2 Similarly, Tilton, in examining the semiconductor industry, hypothesizes that, "The diffusion of new technology is accelerated by a market structure that allows new firms to enter an industry and supplant the established industry leaders whenever the latter fail to employ new techniques as quickly as economic conditions warrant. Hence, diffusion tends to occur faster in countries with flexible market structures than in countries where entry barriers are high and company rankings rigid." ${ }^{3}$ To support this hypothesis, he compares the market share captured by the new firms in the semiconductor industry with their contribution to the technological advancement of the industry. He argues that if a firm captures a share of the market which exceeds their inventive effort as measured by the number of major inventions developed internally by the firm, then they have been instrumental in diffusing

Tilton, International Diffusion, p. 160.

2 E.B. Roberts, "Entrepreneurship and Technology" in Gruber and Margues, Factors in the Transfer of Technology (Cambridge, Mass.: MIT Press, 1969), p. 224.

3 Tilton, International Diffusion, p. 2 
new technology. His examination finds that, "Indeed, the market shares enjoyed by a handful of new firms have greatly surpassed their contribution to the innovative process ... Apparently, these firms have been particularly adept in the diffusion process and have led in using new technology, developed in their own and other laboratories, to produce better, cheaper semiconductor devices."* Therefore, new firms utilizing new technological developments have been able to grow and capture a significant market share. This increases the rate of diffusion of new inventions. Furthermore, in order to stimulate the diffusion of a new production process, it is not essential that these new firms ever capture a large share of the market. As long as the possibility exists for new firms to enter an industry and grow by exploiting a new technology, established firms will be motivated to remain alert to new technological opportunities. Therefore, potential entry can be as important in stimulating the spread of a new production process as actual entry: The crucial factors are the maintenance of low entry barriers and a flexible market structure.

d. Rapid Technological Change. Finally, the fact that the photovoltaic industry is anticipated to exist in an environment of rapid technological advance has important implications for the capital intensity of the production processes adopted by firms: In a regime of rapid technological change it is optimal, from the firm's point of view, to invest less (possibly much less) in capital equipment than in a regime of stable technology. That is, the firm keeps the line flexible to allow adaptation to technological change by operating a labor intensive process. This wás the experience of the early semiconductor industry and is the experience of current photovoltaic suppliers. Only after the technology stabilized did the semiconductor industry switch to more efficient, highly automated, capital intensive production processes. Furthermore, this is precisely the reaction to anticipated technological change which is socially optimal--it prevents the waste of costly capital equipment.

${ }^{*}$ Ibid, p. 69. 
Current plans of the Photovoltaic Program exhibit a glaring inconsistency when viewed in this light. They call for a highly capital intense production process by 1985 to help meet the price goal. However, it is also envisioned that the technology will continue to rapidly advance to lower the production cost an order of magnitude by the year 2000.' (The price goal for the year 2000 is 10-30 c per peak watt). This scenario presents the industry with a di.lemma. Businessmen will be quite reluctant to commit to a highly automated, expensive production process that will be obsolete (uniable to profitably produce) inside of several years. And this is precisely the reaction which is socially optimal--it is not in society's interest, anymore than a businessman's, to "waste" expensive capital equipment. Thus, it serves no socially useful purpose for LSSA or the Photovoltaic Program to attempt to counteract this built-in impediment to the innovation and diffusion of new technologies.

It is inconsistent to plan a highly automated, capital intense production process in the midst of a rapidly changing technology. Tt. is the program plan that is at fault and that should be changed--not the natural and socially correct reaction of private businessmen who will be reluctant to invest in such a situation.

For this reason, among others, Section III recommends that the most advanced stage of the industrialization task--demonstration--not be. undertaken until the technology is well in hand. By this we mean not only that the technology be well developed and understood, but also that it be stabilized.*

It is possible that the potential profit will be so attrartive that the reluctance to invest in capital intensive processes will be overcome. Regardless, we do not consider this problem to be a

* Of course, it would also be possible to back away from the capital intense production process currently envisioned, but discussion of this solution falls into a class excluded from the current topic-price reduction strategies. 
legitimate basis upon which to recommend action (such as subsidies). to facilitate diffusion, as these actions would be facilitating a socially costly and wasteful process. Thus, the assumption is made that either the resulting process is not so inflexible and capital intense as to prevent innovation and diffusion or that the rate of technological change has diminished (stabilized) such that investment in highly automated processes is both privately and publicly. attractive, at which point no impediment is anticipated.

\section{Governmental Barriers}

In many cases, it is government actions which are most potent as impediments to rapid innovation and diffusion. Regulated industries such as railroads, utilities, and bạks, often exhibit slow rates of diffusion. Industries protected by tariffs or quotas from international competition can also be slow to adopt new technologies (see below for a discussion of the iron and steel industry).

Fortunately, however, no particularly important governmental drags on the diffusion process, other than the program plan inconsistency discussed above, is foreseen. The photovoltaic industry is expected to be keenly competitive with little regulation, no important patent barriers, little tariff or quota restric-. tions, etc.

But there is one potential set of government actions which could give rise to innovation and diffusion blockages. These actions consist of Photovoltaic Program and LSSA Project actions with respect to demonstration and commercial production.

Section III recommends that no commercial production of photovoltaic arrays be undertaken by the federal government. Unfortunately, the LSSA project management is constrained by the $500 \mathrm{MW}$ peak/year output goal to plan a government constructed and possibly government-owned commercial plant in the event that the private market does not produce at the prescribed rate. We believe this contingency plan to be extremely detrimental to the innovation and diffusion of photovoltaic technology into the private sector.

Government production for commercial markets has a history of inefficiency and inadequate llallagellint. Furthermore, competition will be stifled (witness the post office) as no government facility is able to survive in a competitive 
regime without large subsidies. Thus, even though photovoltaic output may be increased in the short-term, the long-term effects of government production would be to increase the social costs of photovoltaics, decrease their value to society and possibly to decrease the total long-run quantity of photovoltaics produced and sold. Thus, we recommend that no government production, other than for the purposes of tests and demonstration, be planned or undertaken. (LSSA feels further constrained by two additional output quantities, sometimes referred to as the "X" and "Y" quantities. The most efficient size production plant appears to be 20-50 MW/year. Production process demonstrations should be sized in this range (the $X$ quantity). Furthermore, JPL is currently responsible for supplying arrays to all federal final product demonstrations. Thus, JPL must insure that the combined output from government and private production is adequate to supply these demonstrations (the Y quantity).)

Of course, this does not rule out government subsidies to private production. However, since no important barriers to the innovation and diffusion of new technology are expected, other than those that may arise from the actions of the government, no subsidies to encourage diffusion are considered necessary.

Finally, we recommend that any subsidies planned to encourage the use of photovoltaics in substitution for other sources of energy be applied to the demand side. That is, subsidies should be given to users of photovoltaics rather than suppliers. These subsidies would presumahly be justified on the basis that solar energy avoids the obvious externalities resulting from the use of conventional electricity generation sources. This will not only have the desired effect--substitution of photovoltaics for other energy sources--it will allow the photovoltaic industry to develop in a natural, competitive manner, free of artificial government distortions. This scheme has the added benefit of giving no preferential treatment to any particular suppliers.

Needless-to-say, this does not rule out government participation in or full. funding of pilot and demonstration plants. The next chapter makes specific recommendations in this regard.

In summary, no barriers or impediments to the innovation and diffusion of new photovoltaic production technology arising from information transfer, capital 
availability or market structures are envisioned. Technology transfer is not thought to be an important problem. However, several parts of the program and project plans need to be altered to insure the orderly and rapid development of a competitive photovoltaic supply industry. In particular, the plans for a highly capital intensive production process in conjunction with a rapidly changing technology, as well as the plans for government production of or subsidy to the supply industry, need reconstruction if the program is to proceed to a successful conclusion.

The next section supplements this reasoning with evidence from the semiconductor, petroleum refining, and iron and steel industries.

\section{E. CASE STUDIES*}

Further evidence regarding the expected rate of diffusion of photovoltaic production technology can be obtained by examining the rate of diffusion of new technology experienced in other industries. A comparison of the conditions that existed in these other industries, with those anticipated in the photovoltaic supply industry, can be used to determine if similar rates of diffusion will be experienced by new photovoltaic supply technologies. Three industries will be considered. The semiconductor industry, which has many characteristics similar to those expected in the photovoltaic supply industry, has experienced a rapid rate of diffusion of new technology. The petroleum industry, characterized as having a slow rate of application of new ideas, has actually experienced a rapid rate of diffusion using the narrow definition of industrialization adopted in this study. Finally, the slow rate of adoption of new technology in the iron and steel industry can be attributed to conditions existing in this industry that are not expected in the photovoltaic supply industry.

\section{Semiconductors}

The semiconductor industry is an example of a research-intensive industry which has experienced a rapid rate of diffusion of new technology. Many of the conditions which characterized this industry during its development, and helped

* This section draws particularly heavily on Bill Gates' background paper "Prospects for Innovation and Diffusion of Photovoltaic Technology," taking much of it vérbation. 
to stimulate this rapid rate of diffusion, are expected to exist in the photovoltaic supply industry. Both semiconductors and photovoltaics are based on the refining of semiconductor materials. Currently, silicon is the dominant material in both production processes. Therefore, these industries use many of the same inputs, have the same suppliers, and utilize similar production technologies. (The major difference in technologies is that the semiconductor industry emphasizes decreasing the amount of silicon used and, thus, the size of each unit. In the photovoltaic industry, on the other hand, size is constrained because of the importance of surface area. I'his distinction, however, would not appear to introduce significant differences in firm or industry structure (e.g., size of firms, patent licenses, research intensiveness) and thus in rates of diffusion between these two industries, although it does affect the anticipated rate of cost reduction in the photovoltaic industry.) Because of the similarities, the photovoltaic industry is expected to assume many of the characteristics of the semiconductor industry. Optimal firm size, market structure, the degree of competition on both the national and international level, as well as the policies and regulations adopted by the government for photovoltaics are expected to follow the example of the semiconductor industry.

The photovoltaic industry is a research-intensive industry expecting a rapid rate of technological change. As a result, the existing producers have relied on labor-intensive production processes. 'l'his enables them to avoid capital investment in equipment which would become economically obsolete before sufficient profits accrue to justify the investment. These conditions also characterized the semiconductor industry during its initial stages of development. The early semiconductor industry was also a research-intensive, producer goods industry. It exhibited many of the conditions favorable for the entry of new, technologically based firms. Unexploited technology existed, firms adopted liberal licensing policies, and there was a high degree of interfirm mobility of scientists and engineers. In addition, there were no significant entry barriers. All important economies of scale were captured at low output levels relative to the market size, venture capital was available, and there was a flexible, competitive market structure. Furthermore, federal antitrust, patent, and procurement policies helped maintain an environment which facilitated the entry of new firms. (For further elaboration of these conditions, see John Tilton's book International 
Diffusion: The Case of Semiconductors.) Therefore, the conditions existing in the early semiconductor industry encouraged new firms to enter and exploit unused technological developments. This provided an important stimulus to the diffusion of new ideas in the industry. As Tilton writes, "...new firms with 1ittle or no previous experience in the active-components industry have been the most agressive diffusers of new semiconductor technology." 1 These conditions are also expected to characterize the industry for photovoltaic conversion systems.

Since the photovoltaic industry is expected to experience a development similar to semiconductors, the rate of diffusion of technology in the early semiconductor industry can be used to gain some idea of the expected rate of diffusion in the photovoltaic supply industry. Tilton examines the rate of diffusion of both product and process innovations within the semiconductor industry. A comparison of three tables presented in this study, ${ }^{2}$ reproduced here as Tables 2-1, 2-2, and 2-3, provides evidence on the rate of diffusion of new products and processes in this industry.

Table 2-2 gives the date of development of six new processes which led to new semiconductor products (four other process innovations were not associated with new products). It is apparent that the longest time between date of development of the process and first commercial production (Table 2-1, column 3 ) of the associated new product was one year, products introduced in the same year that the new process was developed which made them possible. Table 2-3 shows that in many cases the original conception, reduction to practice, development and first commercial production all took place within a year or two. Thus, innovation appears to have occurred very rapidly in this industry and an estimate of a 1-2 year lag between development and commercial introduction appears quite reasonable. This conclusion has been supported by Theodore Barry and Associates (TB\&A) in a contract to the $P$, A\&I task in which they estimate that less than a year will be necessary to construct a photovoltaic production line given sufficient floor space. Construction of floor space would require an additional 12-18 months according to TB\&A.

Tilton's study does not explicitly examine the rate at which individual new production processes spread within the semiconductor industry after their

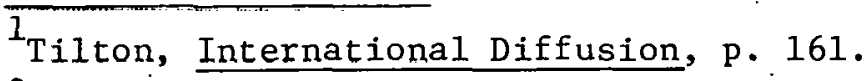

2 Ibid, pp. 16, 17, and 75 .
} 
Table 2-1. Major Product Innovations in the ' Semiconductor Industry, 1951-68

\begin{tabular}{|c|c|c|c|}
\hline Innodation & $\begin{array}{l}\text { Princlpal } \\
\text { firm } \\
\text { responsible }\end{array}$ & $\begin{array}{c}\text { First } \\
\text { commercial } \\
\text { production }\end{array}$ & Importance \\
\hline $\begin{array}{l}\text { Point contact } \\
\text { transistor }\end{array}$ & Western Electric & 1951 & $\begin{array}{l}\text { First solid state amplifier. More efficient in power } \\
\text { consumption, and eventually less costly, more redi. } \\
\text { able, and smaller than tubes. }\end{array}$ \\
\hline $\begin{array}{l}\text { Grown junction } \\
\text { transistor }\end{array}$ & Western Electric & 1951 & $\begin{array}{l}\text { Increased production yield, thus lowering costs. Less } \\
\text { electrical noise and greater resistance to shock. }\end{array}$ \\
\hline $\begin{array}{l}\text { Alloy junction } \\
\text { transistor }\end{array}$ & $\begin{array}{l}\text { General Electric } \\
\text { RCA }\end{array}$ & 1952 & $\begin{array}{l}\text { Greatly improved transistor capability to perform } \\
\text { digital (switching) operations. Encouraged develop- } \\
\text { ment of secondegeneratlou computers. }\end{array}$ \\
\hline $\begin{array}{l}\text { Surface barrier } \\
\text { transistor }\end{array}$ & Philco & 1954 & $\begin{array}{l}\text { Increased tranaistor frequency range and switching } \\
\text { speeds; useful in computer development. }\end{array}$ \\
\hline $\begin{array}{l}\text { Silicon junction } \\
\text { transistor }\end{array}$ & Texas Instruments & 1954 & $\begin{array}{l}\text { First transistor not made from germanium. Silicon } \\
\text { increased temperature range of operation, thus open- } \\
\text { ing up military market. Also increased frequency } \\
\text { range. }\end{array}$ \\
\hline $\begin{array}{l}\text { Diffused } \\
\text { transistor }\end{array}$ & $\begin{array}{l}\text { Western Electric } \\
\text { Texas instruments }\end{array}$ & 1956 & $\begin{array}{l}\text { Lower production costs; increased reliability and } \\
\text { frequency range. }\end{array}$ \\
\hline $\begin{array}{l}\text { Silicon con- } \\
\text { trolled } \\
\text { rectifier }\end{array}$ & General Electric & 1956 & $\begin{array}{l}\text { Valve aflowing electric current to flow in one direc- } \\
\text { tion only, at same time controlling the flow. Can } \\
\text { replace thyratron tubes for control and switching } \\
\text { functions. }\end{array}$ \\
\hline Tunnel diode' & Sony (Japan) & 1957 & $\begin{array}{l}\text { Can replace special purpose tubes for amplitication } \\
\text { and oscillation at very high frequencies. Very fast } \\
\text { but so far too expensive: though a major technical } \\
\text { development, commercial use is limited. }\end{array}$ \\
\hline $\begin{array}{l}\text { Planar } \\
\text { transistor }\end{array}$ & Fairchild & 1960 & $\begin{array}{l}\text { Ratch prndurtion possihle, lowering consts. Improved } \\
\text { performance and reliability. }\end{array}$ \\
\hline $\begin{array}{l}\text { Epltaxial } \\
\text { transistor }\end{array}$ & Western Electric & 1960 & Increased switching speed; lower production costs. \\
\hline $\begin{array}{l}\text { Integrated } \\
\text { rirsuit }\end{array}$ & $\begin{array}{l}\text { Texas Instruments } \\
\text { Fitirchild }\end{array}$ & 1961 & $\begin{array}{l}\text { First semiconductor device with two or more ele- } \\
\text { ments within a silicon substrate. Incorporated bigger } \\
\text { segment of circuit into one device, making increased } \\
\text { reliability, faster switching speeds, lower costs, and } \\
\text { greater miniaturlzation feasible. }\end{array}$ \\
\hline MOS transister & Fairchild & 1962 & $\begin{array}{l}\text { Chesper slow-speed switch. Easy to integrate into clr- } \\
\text { cuit designs. Fewer steps in production process. }\end{array}$ \\
\hline Gunn diode & $\begin{array}{l}\text { International } \\
\text { Businéss } \\
\text { Machines }\end{array}$ & 1963 & $\begin{array}{l}\text { Gallium arsenide device, can replace klystron and } \\
\text { magnetron tubes for generatlon atd usclllutlon It } \\
\text { microwave range. Stilt in experimental and develop- } \\
\text { mont trage. }\end{array}$ \\
\hline
\end{tabular}

a. From 1963 to 1968 , important advances in semiconductor technology were concentrated in the integrated circult field. These innovations are consldered further developments of integrated circuit tochnology and are not separately identified bere. $A$ list is given in Anthony $M$. Golding. "The Semiconductor Industry in Britain and the United States: A Case Study in Innovation, Growth and the Diffusion of Technology" (Ph.D. dissertation, University of Sussex, forthcoming).

b. Company and date indicated are tör the first laboratory model rather than the flrst curninerctal production. 
Table 2-2. Major Process Innovations in the Semiconductor Industry, 1950-68 ${ }^{a}$

\begin{tabular}{|c|c|c|c|c|}
\hline Innooatlon & $\begin{array}{l}\text { Principal } \\
\text { firm } \\
\text { responsible }\end{array}$ & $\begin{array}{l}\text { Date of } \\
\text { deoelop- } \\
\text { ment }\end{array}$ & $\begin{array}{l}\text { Associated } \\
\text { product } \\
\text { innovationb }\end{array}$ & Imporiance \\
\hline $\begin{array}{l}\text { Single crystal } \\
\text { growing }\end{array}$ & $\begin{array}{l}\text { Western } \\
\text { Electric }\end{array}$ & 1950 & $\begin{array}{l}\text { Grown } \\
\text { junction } \\
\text { transistor }\end{array}$ & $\begin{array}{l}\text { Method of growing and doping germanium } \\
\text { crystals. Bell Laboratories (an affiliate of } \\
\text { Western Electric) achieved same Innovation } \\
\text { for silicon cryatals in 1952, leading to silicon } \\
\text { junction transistor. }\end{array}$ \\
\hline Zone refining & $\begin{array}{l}\text { Western } \\
\text { Electric }\end{array}$ & 1950 & e & $\begin{array}{l}\text { Produced extremely pure germanium and illi- } \\
\text { con crystals. Also improved doping process. }\end{array}$ \\
\hline Alloy process & $\begin{array}{l}\text { General } \\
\text { Electric }\end{array}$ & 1952 & $\begin{array}{l}\text { Alloy junction } \\
\text { transistor }\end{array}$ & $\begin{array}{l}\text { Now method for forming Junctions, leading to } \\
\text { transistors with superior switching capabilities. }\end{array}$ \\
\hline 3-5 compounds & $\begin{array}{l}\text { Siemen: } \\
\text { (Germany) }\end{array}$ & 1952 & & $\begin{array}{l}\text { Semiconductor materials made from combi- } \\
\text { nations of elements in third and fifth groups of } \\
\text { periodic table, such as gallium arsenide. Later } \\
\text { used in the Gunn diode. }\end{array}$ \\
\hline Jet etching & Philco & 1953 & $\begin{array}{l}\text { Surface } \\
\text { barrier }\end{array}$ & $\begin{array}{l}\text { Process for producing transistors with in- } \\
\text { creased frequency and switching properties. }\end{array}$ \\
\hline & & & transistor & 1 \\
\hline $\begin{array}{l}\text { Oxide masking } \\
\text { and diffusione }\end{array}$ & $\begin{array}{l}\text { Western } \\
\text { Electric }\end{array}$ & 1955 & $\begin{array}{l}\text { Diffused } \\
\text { transistor }\end{array}$ & $\begin{array}{l}\text { Improved method for forming junctions. } \\
\text { Batch production possible, reduclng produc- } \\
\text { tion costs. Also improved quality control; } \\
\text { increased power and frequency capabilities of } \\
\text { transistors, diodes, and rectifers. }\end{array}$ \\
\hline Planar process & Fairchild & 1960 & $\begin{array}{l}\text { Ptanar } \\
\text { transigtor }\end{array}$ & $\begin{array}{l}\text { Development on oxide masking and diffuiton } \\
\text { process that lowered production costs and im- } \\
\text { proved performance characteristics; of great } \\
\text { importance for economical production of inte- } \\
\text { grated ctrcuits. }\end{array}$ \\
\hline $\begin{array}{r}\text { Epitaxial } \\
\text { process } \\
\end{array}$ & $\begin{array}{l}\text { Western } \\
\text { Electric }\end{array}$ & 1960 & $\begin{array}{l}\text { Epitaxial } \\
\text { transistor }\end{array}$ & $\begin{array}{l}\text { Technique for junction forming whereby one } \\
\text { type of crystal structure is grown on another. } \\
\text { Used with planar process, it reduces produc- } \\
\text { tion costs and increases performance charac } \\
\text { teristics, particularly frequency range, of } \\
\text { transistors and integrated efrcuits. }\end{array}$ \\
\hline $\begin{array}{l}\text { Plastic } \\
\text { encapsulation }\end{array}$ & $\begin{array}{l}\text { General } \\
\text { Electric }\end{array}$ & $1963^{d}$ & v & $\begin{array}{l}\text { Inexpensive method of protecting transiators } \\
\text { and integrated circuit from contamination } \\
\text { when reliability is not crucial. Thougb impor- } \\
\text { tant commercially, not a major technical } \\
\text { advance. }\end{array}$ \\
\hline Beam lead & $\begin{array}{l}\text { Western } \\
\text { Electric }\end{array}$ & 1964 & & $\begin{array}{l}\text { Reduces encapsulation costs for highly reltable } \\
\text { semiconductor devices. Permits alr isolation of } \\
\text { integrated circuit elements, and facilitates } \\
\text { mixing of semiconductor and thin-film tech- } \\
\text { nologles in hybrid integrated circuits. }\end{array}$ \\
\hline
\end{tabular}

a. From 1964 to 1968, important advances in semiconductor technology were concentrated in the integrated circuit field. These innovations are considered further developments of integrated circuit technology and are not separately identified here. $A$ list is given in Cinlding. "The Semiconductor Induatry in Britain and the United States."

b. When the new process led directly to one of the new semiconductor products listed in Table 2-1, this column indicates the product.

c. Up to this point, diffusion has referred to the transfer or dissemination of technology. The term is also used in this study, as it is here, to identify a specific process used in memiconductor production. The meaning intended is apparent from the contert.

d. Plastic encapsulation was known in the 1950 s but was not practical for commercial use. 
Table 2-3. Dates of Conception, Reduction to. Practice, and First

Publication for Major Semiconductor Innovations Achieved by

Be11 Laboratories, 1947-68 ${ }^{\mathrm{a}}$

\begin{tabular}{llll}
\hline \multicolumn{1}{c}{ Innooation } & Conception & $\begin{array}{l}\text { Reduction } \\
\text { to practice }\end{array}$ & $\begin{array}{c}\text { First } \\
\text { publication }\end{array}$ \\
\hline Point contact transistor & Dec. 1947 & Dec. 1947 & June 1948 \\
Zone refining & May 1950 & Oct. 1950 & Feb. 1952 \\
Silicon diffusion & Feb. 1954 & Feb. 1954 & June 1954 \\
Diffused base transistor (mesa type) & Dec. 1953 & July 1954 & June 1955 \\
Silicon diffused base transistor & March 1955 & March 1955 & June 1955 \\
Oxide musking for diffusion & June 1955 & Aug. 1955 & Jan. 1956 \\
Epitaxial transistor & Sept. 1959 & Feb. 1960 & June 1960 \\
Beam lead & Fall 1963 & Spring 1964 & Oct. 1964 \\
\hline
\end{tabular}

Source: Correspondence with Bell Laboratories.

a. This table lists only the major innovations identified in Tables 2-1 and 2-2, none of which were introdiucid by Dell Labusatories after $19 G$.

initial commercial application. Two factors, however, indicate that this also occurred at a swift rate. The first factor is the rapid increase in the share of the semiconductor market captured by new firms introducing a new technology. Texas Instruments, Transitron, and Fairchild, among others, a11 used product and process innovations to enter and capture significant shares of the semiconductor market. For example, Tilton writes, "The second largest semiconductor producer. in the 1ate 1950's was Transitron, a small new firm whose growth and success were also built on a new product. Bell Laboratories developed the first gold-bonded diode, but Transitron was the first to work out the many problems associated with large-volume production and to achieve yields high enough to permit a price competitive with the less reliable point-contact diode then in use. The goldbonded diode launched the new firm..."* Thus, Transitron was able to become the second largest semiconductor firm (second to Texas Instruments, another new, technologically based firm) as a result of a process innovation that allowed it to effectively market a better quality product at a lower price. Thus, evidence indicates that diffusion of a new technolugy through the growth of the innovator occurred rapidly in the semfconductor industry. In addition, Tilton indicates that diffusion by imitation proceeded quickly also. In discussing a new product ! developed by. Texas Instruments, he writes, "Texas Instrument's lead in this

${ }^{*}$ Ibid, pp. 66-67. 
development lasted some two or three years, a remarkably long time in an industry where firms usually can duplicate a new device and second-source the innovator in six months." 1

Finally, Tilton considers the rapidity with which semiconductor devices as a whole replaced conventional active component production. He concludes ${ }^{2}$ :

The penetration of semiconductor technology among activecomponent producers proceeded swiftly in all countries [U.S., Britain, Japan, France, Germany] during the 1950's except possibly Britain where the data are incomplete. .... The preceeding measures of diffusion indicate that new semiconductor technology spread rapidly to and within the countries considered.

Comparing the ratio of semiconductor production to active-component production with that of semiconductor usage to active-component usage, he concludes that diffusion of semiconductor technology is limited primarily from the product demand side:

Competent semiconductor firms can normally duplicate new devices within six to, twelve months. .... So demand, rather than supply, apparently is also the relevant constraint on diffusion of semiconductor use. 3

Therefore, evidence from the semiconductor industry indicates that the lag between the establishment of technological and economic feasibility and the first commercial application of the new technique was very short. Furthermore, though actual data is not given, the implication is that diffusion within the industry, both through imitation by other firms in the industry and through the growth of the innovator, proceeded at a swift pace once the initial application of the new technology had occurred. Thus, the semiconductor industry experienced a rapid rate of diffusion of new technology. Tilton stresses, "Although the impact of the many factors affecting diffusion cannot be precisely separated, several considerations suggest that diffusion has proceeded as quickly as justified by

\footnotetext{
${ }^{1}$ Ibid, pp. 65-66

2 Ibid, pp. 30,34

3 Ibid, pp. $37-38$
} 
demand conditions in the countries considered..."1 In other words, given technological and economic feasibility, and an effective market demand, industrialization of semiconductor technology occurred.without any significant lags. A delay of one to two years is a reasonable estimate of the lag between completion of the invention stage and the time that the new process is commercially producing and filling market demands.

\section{Petroleum Refining}

Studies of the rate of diffusion of rechnology in other industries are quite scarce and have obtained less optimistic results. Enos, after examining the diffusion of new production processes in the petroleum industry states, "Giving each invention equal weight, we obtain for the sample of eleven observations an arithmetic mean interval between invention and innovation of 11.0 years and a median of 11 . For the sample of nine observations the mean is 12.8 years and the median, 13. The standard deviations are 4.6 and 3.0 respectively:" 2 Thus, Enos indicates that there were significant lags in the adoption of new production technology in the petroleum refining industry. The presence of these delays, however, can be accounted for by the definitions of invention and innovation that Enos uses. He defines invention as the original conception of the new idea. Innovation, on the other hand, includes its subsequent development and proof of technological and economic feasibility, as well as the establishment of an effective market demand. If Enos' definitions of invention and innovation are modified to coincide with the ones used in this report, the lags found in the adoption of petroleum refining technology disappear. For example, he characterizes the Houdry process, a semi-continuous process for the catalytic cracking of oil and catalyst regeneration, as experiencing a nine-year lag between invention (1927) and the first commercial application (1936). In describing this innovation, however, Enos limplies that cechnological feaslbility was nut established until 1936. He writes, "By 1936 the difficulties in the design of the equipment had been overcome to the point where a commercial installation could be made." 3 .

\footnotetext{
I Ibid, p. 35 .

2 John Enos, "Invention and Innovation in the Petroleum Refining Industry", in The Rate and Direction of Inventive Activity, National Bureau of Economic Research (Princeton: Princeton Univ. Press, 1962), p. 306. ${ }^{3}$ Ibid, p. 302.
} 
The difference in definitions adopted is also illustrated by the development of fluid catalytic cracking. Enos finds a thirteen year lag between invention and innovation for this new process (1929-1942). Yet, in describing the development of this process he states, "Odell's application for a patent on a process of producing reactions.using a fluidized bed of powdered catalyst was made in 1929... The majority of the developmental work, however, was carried out in the five years, 1938-1942, preceeding the first commercial installation." ${ }^{1}$ Therefore, there is no evidence of significant barriers to the introduction of new technology in this industry once technological and economic feasibility have been established, and an effective market demand exists for the output of the new process.

\section{Iron and Stee1}

A final piece of information on the rate of diffusion of production technologies is found in a study of the iron and steel industry by Walter Adams and Joel Dirlam. They examined the adoption in the United States of the oxygen steel making process. In describing the process they state, "Not only does it produce top-grade, 'open-hearth' quality steel more quickly and efficiently than older methods, but it entails lower investment (as well as operation) costs." ${ }^{2}$ Thus, the new production process would enable a firm to manufacture the same output for a lower cost. Nevertheless, even though the technical feasibility of the process had been proven by late 1950, and the process was embodied in an Austrian plant which began large scale commercial operations in 1952, adoption by the three major U.S. steel producers did not occur until 1964. (U.S. Steel and Bethlehem in 1964, Republic in 1965). Diffusion of this technology in the United States. was initiated by the smaller.firms in the industry. As Adams and Dirlam describe, "...the innovator of oxygen steel making in the United States was the twelfth largest steel company (McLouth) in 1954, to be followed by the fourth largest (Jones and Laughlin) in 1957, the ninth largest (Kaiser) in 1958, the nineteenth largest (Acme) in 1959, the tenth largest (Colorado Fuel and Iron) in 1961, the fifth largest (National) in 1962, and by the fifteenth largest

\footnotetext{
Ibid, pp. 303-304

2 Wa1ter Adams and Joel Dirlam, "Big Steel, Invention and Innovation," The Quarterly Journal of Economics, May 1966, p. 169.
} 
(Pittsburgh), twenty-second largest (Allegheny-Ludlum), and the sixth largest (Armco) in 1963."* Thus, not only was the rate of diffusion of the oxygen process very slow, the proportion of the industry's output produced by this process was extremely low until the major producers began utilizing the process in 1964 (less than $8 \%$ of industry output was produced by this process in 1963 ).

There are differences, however, in the conditions existing in the iron and steel industry and those expected in the photovoltaic supply industry. These differences may explain why delays in the diffusion process are observed in the former industry, while no such lags are anticipated in the latter. In the first place, the iron and steel industry is a technologically stable rather than a. research intensive industry, with innovations occurring rather infrequently. Therefore, production techniques tend to be capital-intensive and require slgnificant investment. Furthermore, this capital has a long expected physical lifespan. In addition, the industry has been characterized by a relatively inflexible oligopolistic market structure. Encroachment on the market shares of the industry leaders has not come from the entrance and growth of new domestic firms, but rather from foreign producers. Finally, the U.S. steel industry has been losing its comparative advantage over foreign producers for some time. Thus, the domestic steel industry has been contracting--not a situation conducive to rapid and widespread adoption of new production techniques. Together, these conditions have created significant barriers to the widespread diffusion of new production technology in the iron and steel industry.

Due to the stable technology, opportunities for new technologically based firms to enter and challenge the established industry leaders have been limited. The capital investment and large scale of operation required in order to effectively compete in this industry may have raised significant entry barriers. Furthermore, the inability of a new firm to displace the industry leaders by exploiting a new technology has reduced the lncenllve Lo Lncur lite lisks uf innovation. The inflexibility of the market structure is verified by the fact that even though the smaller firms adopted the more efficient oxygen steel making technique up to eleven years before the three largest firms, these three firms

* Ibid; p. 183 
still maintained their domestic market dominance, presumably by remaining competitively priced with the small firms. Thus, the industry leaders have not been stimulated to adopt new production techniques by the potential entrance of new technologically based firms. A major source of competition comes from foreign producers. As Ault writes, "During the late 50's and 60's, the slowness of U.S. producers to adopt BOG (oxygen process) appears to have contributed to the rapid deterioration of their ability to compete in the world steel market during that period." ${ }^{*}$ Competition from foreign producers, however, is limited due to import quotas, tariffs and other artificial barriers to international trade. Therefore, domestic firms are partially insulated from the competition provided by foreign. producers. As a result, the incentive provided by foreign producers does not seem to have had a large effect. Thus, even though the rate of new process. diffusion was quite slow in this industry, the causes of this tardiness would not appear to apply to the anticipated photovoltaic supply industry.

\section{F. SUMMARY}

To summarize the analysis thus far, both theoretical arguments and an examination of case studies verify that no significant lags to the diffusion of new production technology in the photovoltaic supply industry should be expected. This analysis assumes that technological and economic feasibility have been established and that an effective market demand exists for photovoltaic conversion systems at the targeted price of $50 \mathrm{c} /$ peak watt. Based on these assumptions, theoretical arguments indicate that research-intensive industries characterized by a flexible, competitive market structure will not experience barriers to the diffusion of new production processes. Barriers are only expected if created by government actions. Empirical evidence provided by case studies of the diffusion of production technology in other industries supports these conclusions. Diffusion was found to occur rapidly in the semiconductor industry, which is characterized as a research-intensive, competitive industry. Furthermore, lags in the diffusion of technology in the petroleum refining industry and the iron and steel industry can be explained by differences in either definitions used or in the

"David Ault, "The Continued Deterioration of the Competitive Ability of the U.S. Steel Industry: The Development of Continuous Casting," Western Economic Journal, March 1973, p. 95. 
economic and technological environment of the industry. Thus, both theoretical and empirical evidence imply that industrialization of new production technology will occur as rapidly as demand for the output of the new process warrants.

Evidence indicates that a delay of one to two years is a reasonable estimate of the time between the establishment of technical, economic, and commercial feasibility, and the moment the new process is commercially producing and filling market demands. This interval is necessary to arrange financing, establish production facilities, train labor, obtain inputs, and initiate production. Furthermore, new production processes will spread within the industry at approximately the socially optimal rate once the initial application of the technology has occurred. This does not imply the immediate replacement of all existing capital by capital embodying the new techniques. Instead, the spread of new technology will be related to the rate at which capital of an older vintage becomes economically obsolete and the growth rate of the industry. In a competitive industry, however, the establishment of a new market price will occur before the diffusion process has been completed. Therefore, significant delays in the diffusion of new production technology, or in the establishment of a new market price, are not expected in the photovoltaic supply industry.

The following section examines the $1986500 \mathrm{MW}$ peak/year production target of the LSSA project in light of these conclusions.

\section{G. OUTPUT TARGET}

The introduction to this paper established three possible motivations for the $500 \mathrm{MW}$ peak/year 1986 production target set for the photovoltalc supply industry:

(1) as an aid to assure the adoption of the new production technologies;

(2) as an ultimate test against which the photovoltaic program may be judged a success or failure--one percent of annual additions to total United States electrical production capacity;

(3) as an aid in the attainment of the price goal through the learning curve phenomenon.

We have argued that the first motivation for this target is redundant-sufficient output will quickly be forthcoming without government prodding. 
The other two motivations may have different implications for the disposition of the quantity output target. If the target is an ultimate standard against which the success of the program will be tested, then the target should be shifted from the JPL/LSSA project to Program Headquarters at ERDA, as the goal applies to the entire program, not just LSSA. Furthermore, the target should not be an operational goal whose attainment, by whatever means, is required for success. Rather, it should be a passive target, which, if reached through the successful reduction in output price by the program and subsequent production and sale by private industry to ultimate consumers, is an indication that those price reduction and demand stimulation activities were indeed successful. Put differently, it. should not be a target which can be met through government production.

Finally, if it is intended as a tool to aid in the attainment of the 1986 price goal, then it should be called a tool-not a separate goal of the program. It should clearly be made subsidiary to and a part of the price goal of the LSSA project. Furthermore, there is little justification for adopting any particular quantity if it is meant as a project tool. Rather, the proper amount of output for each year of the program should be derived through the same type of analysis that derives the best amount spent on each of the other tools used to reduce the output price. That is, it makes no more sense to specify, a priori, the exact allocation of the output tool than to specify the exact amount to spend on each of the other processes which hopefully will lead to price reductions. This should be a project management decision, subject to change to arrive at the best allocation of project resources to attain the price goal in as efficient a manner as possible. Thus, in this case we recommend dropping the output goal.*

Hence, depending on the motivation behind the quantity output goal, we recommend that either it be transferred to Program Headquarters as an ultimate, passive standard against which the success of the Photovoltaic Program can be tested or that it be dropped altogether.

Section III proceeds with a discussion of the implications of this analysis for the experimental plant plans of the LSSA project.

\footnotetext{
* See Section II.D. 4 for a discussion of two further quantity constraints on the LSSA project arising from tests and demonstrations (the " $\mathrm{X}$ " and " $Y$ " quantities).
} 


\section{SECTION III}

THE CONCORDE SYNDROME:

...Recent experience strongly suggests that projects receiving sizable government support are likely to suffer from an entirely different dynamic, one where it becomes increasingly difficult to cut off expenditures upon projects to which a government and its bureaucracy have already made a heavy commitment of finance and prestige. It is characteristic of such projects that firm and essentially irreversible large-scale financial commitments are made at a very early stage when the technical knowledge necessary for intelligent decisions is necessarily fragmentary, and when therefore the level of uncertainty is still very high. I would not be entirely surprised if, in ten years time, this propensity were to be referred to as the "Concorde Syndrome". In the meantime, I would suggest we remain highly skeptical concerning the commitment of sizable public funds to the final stages of commercial exploitation of a new .... technology. Although there is a persuasive case to be made for government support of basic research and for exploratory technological development in some specific areas, such a case has little pertinence to decisions concerning the final development and commercial exploitation of new or improved products.

--Nathan Rosenberg, 1977*

\section{A. INTRODUCTION}

Section II argued that once the price objective (50c/peak watt) has been achieved by the Technology Development branch of the Photovoltaic Program, any government incentives to promote acceptance of the product should be aimed at users rather than suppliers. The major support for this assertion came from evidence which showed that government efforts to promote supplier acceptance, given the' $50 \mathrm{c} /$ peak watt price and user acceptance (market demand), would be redundant--supply will readily appear without any government prodding. Furthermore, it was argued that the encouragement of user rather than supplier acceptance has several additional advantages, not the least of which is the promotion of competition among photovoltaic suppliers.

\footnotetext{
${ }^{*}$ United States Congress, studies prepared for the use of the Joint Economic Committee, U.S. Economic Growth from 1976 to 1986: Prospects, Problems, and Patterns, (Washington, D.C.: Government Printing Office, Jan. 1977). Technological Change, Vol. 9, p. 32.
} 
This conclusion has implications for several parts of the Low-Cost Silicon Solar Array Project. In particular, the plans for government involvement in supply technology demonstrations and commercial production are affected. The present chapter examines the spectrum of issues related to such experimental plants, including pilot, demonstration and commercial scale production plants.

The conclusions are that:

(1) Pilot Plants should be used as part of the Research and Development effort. That is, they should be constructed whenever it is determined they would be advantageous from a Technology Development perspective.

(2) Demonstration Plants should be built only when the technology is well in hand. They should be aimed at information production, not information transfer. However, the information they produce should be primarily, if not exclusively, economic (not technological). -

(3) Commercial scale production should not be undertaken as part of the Photovoltaic Program.

These conclusions are advanced on the basis of both a priori reasoning and a thorough analysis of previous federal efforts to promote a technology through demonstration projects. The factors which have made such demonstrations successful are analyzed and used to derive detailed recommendations for the implementation of pilot/demonstration plants in the LSSA project.

The discussion proceeds as follows. First, the current LSSA plans for pilot, demonstration and commercial scale plants are reviewed in Section III.B. Next, operational definitions of the various types of experimental plants are derived, and the implicationo of thesc definitions arc spclled out in section III.C. Sections III.D and III.E discuss pilot plants and demonstration plants, respectively, and Section IV presents conclusions and recommendations. Evidence from a voluminous Rand Corporation study entitled Analysis of Federally Funded Demonstration Project.s * is used to support the analysis throughout.

*Walter S: Baer, Leland L. Johnson, and Edward W. Merrow, Analysis of Federally Fundèd Demonstration Projects, Three Volumes: Executive Summary (R-1925-DOC), Finä1 Report (R-1926-DOC), Case Studies (R-1927-DOC), (Rarid Corporation, April:1976). 
B. LSSA PLANS

The most recent statements of Photovoltaic Program and LSSA Project plans are found in the National Solar Photovoltaic Program Plan: Draft. ${ }^{1}$ Here, plans are drawn for pilot and demonstration plants for the Silicon Material, the Silicon Sheet Technology, and the Automated Array Assembly tasks of the Technology Development branch of the Project. Designs for two silicon material (semiconductor grade and solar grade) "experimental facilities" are to be completed by July 1979 with operations beginning between March and June of 19.81 . Designs for a demonstration plant (for silicon material) are to be completed by February 1982, with operations beginning in October of 1985. Plans for the Silicon Sheet Technology are less specific: an experimental plant is to be producing by June 1983 and a "mass production plant" is to be operational by September of 1985. Finally, the Automated Array Assembly task will commit to the design of an experimental line early in 1981, begin operation demonstrations in early 1984, and have a mass production facility operational by late $1985 .^{2}$

One fact stands out from these schedules: there will be no time to evaluate the results of pilot (experimental) plant operations and use that evaluation in the design of the demonstration (mass production) plants. The demonstration plant designs are finalized at the time the pilot plants are scheduled to begin operations. Several important implications of this fact will be elaborated upon below.

There is also considerable confusion over the definitions and purposes of pilot, demonstration and commercial scale plants. Consider the following statements taken from the plans for the Silicon Material, Silicon Sheet, and Automated Array Assembly (recently relabelled the Production Process and Equipment Area) tasks respectively:

Establishment of process feasibility (including process sizescale effects) will be followed by phases for the design, construction and operation of experimental production facilities and pilot plants.

\footnotetext{
$I_{\text {The Photovoltaic Program Planning Group, National Solar Photovoltaic Program }}$ Plan, unpublished document, July 1977. Although this document was never accepted as a Program Plan, it nevertheless summarizes the views of many of the prominent decision makers in the Photovoltaic Program.

2 Ibid, pp. 48-65.
} 
This will allow the technical and economic feasibility to be established on representatively sized facilities.... The design and construction of a pilot plant will take $2-1 / 4$ years. This plant will be operated until commercial plants are well established. The concurrent operation of the pilot plant and the commercial plant will permit the pilot plant to be used for process optimization, problem solving, and studies of process modifications. 1 (Silicon Material Task)

A final milestone in this task is the construction of an experimental plant which incorporates the leading sheet processes into a large-scale, solar array automated production plant in FY85. The plant may utilize multiple methods of sheet production rather than a single growth method to toster industrial comperdion. ${ }^{2}$ (51licon Sheet Task)

The exper1mental. plant desigued in the previous phase will be constructed and operated, and its performance will be evaluated. During the period of operation detailed evaluations of equipment and processes will result in mudifications and optimization as required. The technical and economic feasibility of large scale commercial production facilities will be established.

The construction, operation and evaluation of the experimental line is expected to take approximately three years...

The final phase of automated assembly technology development is to incorporate the knowledge and experience gained from the experimental line into the design of a large scale commercial production plant. The results of thi.s phase represent the culmination of the objectives and goals of the Low-Coet Silicon Solar Array Project. The large scale commercial plant will be capahle of demonstrating the industry's capacity of more than 500 peak megawatts and a 20year useful life time at a price not to exceed $\$ 0.50$ per peak watt. ${ }^{3}$ (Production Process and Equipment Area).

The confusion between experimentation and commercial production in these statements results from the pressure to develop new technology and meet the 500 MW peak/year production goal simultaneously. Since the technology for producing cheap electricity from photovoltaics is still undeveloped, experimental lines (pilot plants) are considered essential to the development process. However, LSSA management is constrained to guarantee meeting the $500 \mathrm{MW}$ peak/goal by

\footnotetext{
Ibid, p. 50 .

? Ibit, p. 56 .

3 Ibid, p. 63 .
} 
planning to construct a similar industrial capacity. Thus, the timing of the pilot plants and commercial plants are collapsed to occur in parallel. 1

This section argues that this is both unwise and unnecessary: Section $C$ begins this argument with definitions and statements of purpose for pilot, demonstration and commercial scale production plants respectively.

\section{DEFINITIONS AND PURPOSES}

The encyclopedia defines a pilot plant as: "...a scale model of a larger plant or a portion thereof, built of engineering materials and operated for a relatively short period of time to produce engineering design data for the process, or trial lot quantities, or both." 2

According to section 1(c) of the Demonstration Plants Act of 1958, P.L. 85-883, a demonstration plant is defined as: "...a plant of sufficient size and capacity to establish on a day-to-day operating basis the optimum attainable reliability, engineering, operating and economic potential."

Thus, both demonstration and pilot plants are aimed at the generation of information--the reduction of uncertainty. However, the types of information they produce are quite different. Pilot plants are primarily concerned with the resolution of technological uncertainties, while demonstrations are primarily aimed at the reduction of economic uncertainty.

There are at least five sources of uncertainty which must be lowered to manageable levels before private commercial production employing a new technology can take place. The Rand Study Analysis of Federally Funded Demonstration Projects has classified experimental plants according to their success at producing information which lowered the following uncertainties:

(1) Technological uncertainty: uncertainty as to the operating characteristics and feasibility of a new technology.

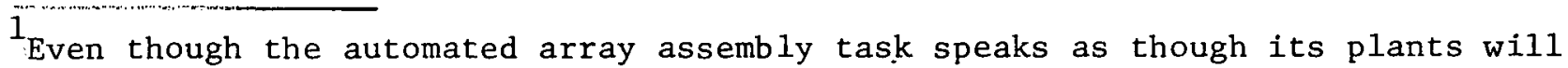
be built sequentially, it is extremely unlikely that there will be enough time to utilize the results of pilot plant experimentation in the designs for the commercial scale plant.

2 Donald G. Jordan, Kirk-Othmer Encyclopedia of Chemical Technology, Volume 15, Second Edition, (New York: Interscience Publishers, 1968), p. 607. 
(2) Cost uncertainty: uncertainty with respect to the total per unit costs of production.

(3) Demand uncertainty: uncertainty as to the market demand for the product as a function of time and product price.

(4) Institutional uncertainty: uncertainty as to the competence and relevance of the institutional arrangements, both internal to the firm (organizational structure) and external (regulation).

(5) Externality uncertainty: uncertainty with respect to the level of external benefits or costs associated with the technology. (External benefits or costs are those costs or benefits imposed on individuals not involved in the actual transaction. Examples include all types of pollution and dependence on foreign oil.)

The primary purpose of a pilot plant is to reduce the first of these--the level of technological uncertainty. Although some information about the other four categories may be generated, a pilot plant is an important part of the research and development effort, and should be built whenever it is considered the most efficient manner in which to reduce the level of technological uncertainty.

A demonstration plant, on the other hand, is aimed primarily at one or more of the other four categories of uncertainty. Although it may generate some technological data, it is built for the purpose of deriving reliable estimates of unit costs, market demand, etc.

Thus, pilot plants and demonstration plants are distinguished by the functions they perform. Furthermore, it is this functional distinction which determines their optimal design parameters, operating characteristics, political environment, and funding arrangements.

A common mistake is to assume pilot plants and demonstration plants are differentiated primarily by size. Although a demonstration is often larger than a pilot plant because their various tunctions call for different size operations, it is the different functions, not the different designs, which distinguish them. For example, a pilot plant can never become a demonstration simply by making it larger--it only becomes an oversized and poorly deslgned pilot plant. Such a plant will be both a poor demonstration and an inefficient pilot. 
This emphasis of function makes it clear that pilot plants must precede demonstrations. The output of pilot plant experiments is essential to the proper design and planning of demonstrations. It is not possible to make accurate estimates of costs, demand, externalities or regulatory constraints until the technology. has become well defined. Attempts at demonstrations before the technology is ready have resulted in inefficiently scaled experimental plants which function poorly as either demonstrations or pilot plants and at great cost. Examples of such failures are cited below.

The sequential transition from pilot to demonstration applies equally to the third step--commercial production. A commercial plant's primary purpose is the production of physical output at the least possible cost per unit for sale in an open market. Significant production will occur only when all five types of uncertainty have been reduced to acceptably low levels. Not only is the techno1ogy well in hand, reliability determined, etc., but accurate estimates of demand and cost, externalities, and relevant organizational and regulatory constraints have been compiled. With this information a commercial plant can be designed to produce at the least cost per unit (efficient scale, mix of resources, material handling, etc.) Without this information, attempts at commercial production are unlikely to succeed. Only luck can prevent the construction of an inefficient plant. If such a plant is constructed, it will not survive in a competitive market, as competitors will undersell it as soon as the missing infprmation is compiled and applied to the construction of subsequent plants.

Thus, the sequence--pilot, demonstration, commercial production--is of utmost importance to the proper and successful introduction of a new technology.

Sections III.D and III.E present evidence on previous federally funded demonstrations and the determinants of their success or failure.

\section{PILOT PLANTS}

As pointed out above, the primary function of a pilot plant is to resolve technological issues. This has definite implications for their design and implementation. Consider the following result from a study of pilot plant experience in the chemical industry*:

\footnotetext{
${ }^{\star}$ Jordan, Chemical Encyclopedia, p. 610.
} 
It is quite difficult to operate such pilot plants. They, are constantly plagued by relatively trivial mechanical difficulties that arise because of the unknown characteristics of the process, the experimental nature of the operations, and the intermediate size of the apparatus. Pilot plants are of ten required to work under conditions that are far from optimum. The equipment is usually relatively small so that it is easily upset, hard to control, readily plugged by dirt or polymer, and so small that ordinary maintenance is not easy. Heat losses can be high so that heat balances are difficult to make, and material losses can be substantial so that careful attention to detail is necessary before a good material balance is obtained. The engineers and technicians working on these pilot plants spend $85 \%$ of their time struggling with the apparatus in an effort to make it work.

The operations of a pilot plant are constantly interrupted by technological problems. Alternative techniques or processes must be implemented to improve performance or correct deficiencies. Thus, attempts to gather data on reliability and cost from the pilot plant will be seriously handicapped.

Evidence as to the efficiency of conducting demonstrations either without, or concurrently with, a pilot plant can be found in the Rand Study referred to earlier. Here, twenty-two federally funded demonstrations were classified as to their level of technological uncertainty. Table 3-1 tabulates these rankings against three distinct measures of success. Each project was judged as to its level of success at (1) reducing the uncertainties in all five dimensions cited above to acceptably low levels (information success); (2) producing a useful output or product (application success); and (3) selmularing subsequent ditfuslun of the technology (diffusion success).

Table 3-1 shows that in no demonstration where preproject technological uncertainty was high was there success at either reducing uncertainty to low levels or stimulating subsequent diffusion of the technology. And, although a number of projects with medium preproject technological uncertainty were judged information successes, in only 3 of 8 cases was the subsequent diffusion significant. Thus, demonstrations conducted with high technological uncertainty are highly likely to fail.

'lhe Rand síudy expla1ns these results as followst:

The association between diffusion success and low or medium technology uncertainty is not surprising. The value of a demonstration project in generating information useful to potential adopters depends on its

$\bar{*}$ Rand, Analysis of Demonstrations, Vol. 2, pp. 46-47. 
Table 3-1. Technological Uncertainty vs. Project Success

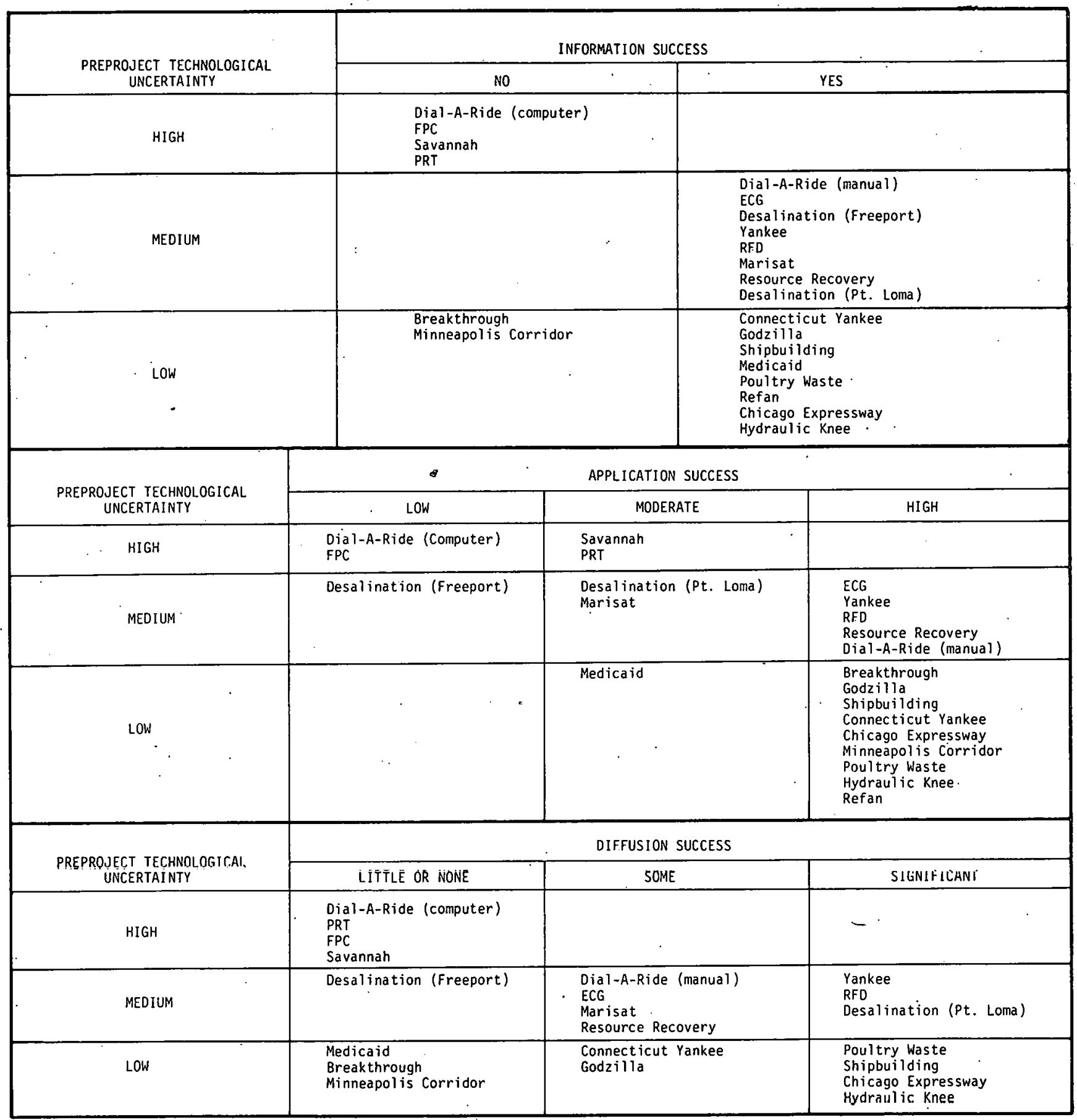

SOURCE: Reprinted from Analys is of Federally Funded Demonstration Projects: Final Report, Walter S. Baer, Leland L. Johnson, and Edward W. Merrow, (Santa Monica: Rand Corporation, April 1976), pp. 47, 175-776. 
operating reliability in a real-world environment. If the technology is not well in hand, there will be frequent breakdowns, delays, and frustrations. Whatever would have been gained in the real environment, such as obtaining a better understanding of the demand for the product, is thereby lost or at least severely compromised.

The highly uncertain technology with which pilot plants deal has implications for both their design and implementation. In general, pilot plants should:

(1) be as small as is technically feasible

(2) have a flexible design

(3) concentrate on the resolution of technical uncertainties

(4) keep a 1 nw pol1t.1s.a1 profile.

Given that the technology is not well understood, substantial changes in the initial pilot facility must be anticipated. Therefore, individual process units should be built at the minimum possible scale necessary to resolve technical issues in order to minimize the costs of alterations, design changes, etc. Each process unit should be built keeping in mind the objective of scaling up to commercial size. Thus, some readily scalable processes may be well-defined at the laboratory stage and need not be included in the pilot. On the other hand, if process integration or product output (e.g. for technical or market testing) are important, then all processes will have to be included.

Furthermore, each process should be deliberately designed with the possibility of alteration in mind, so that subsequent changes are not hindered.. Thus, the pilot plant should be small and flexible.

Since the pilot plant is deliberately built with the anticipation of changes, implying a small, flexible scale, it is unlikely that uncertainties with respect to cost, product demand, externalities, etc. will be completely resolved. Hence, the pilot should concentrate on rechnical problems, although any useful information concerning the other dimensions of uncertainty will, of course, be utilized.

Finaldy, it is desirable that a pilot have a low pol1tical profile. Th1s objective is facilitated by the small size and relatively small cost of demonstrations. The effect of giving too much visibility to pilot plants, with their 
frequent shutdowns and frustrations, can be disastrous. There is a real danger that such information will be interpreted as a sign of failure. A prime example is the Freeport, Texas demonstration of the long vertical tube evaporation (VTE) process for the desalination of ocean water conducted by the office of Saline Water (OSW) from 1961-1965. Much of the impetus for undertaking the demonstration originated in Congress ${ }^{1}$ :

It has been suggested that the processes that were demonstrated would have been kept in the laboratory development phase for years if Congress had not mandated the demonstrations, which suggests that at least some of the processes were not ready for implementation on the scale of a demonstration plant.

Furthermore, the plant remained in the political spotlight ${ }^{2}$ :

Although there were technical difficulties with the Freeport plant (Demonstration Plant No. 1), it seems to have been a showpiece of the demonstration plant program. There were several visits by diplomats and foreign technical teams to the Freeport facility. OSW became an international clearinghouse for desalting information...

The principal objective of the demonstration was identical to that of $\operatorname{LSSA}^{3}:$

The principles involved in the production of fresh water from saline water at Freeport are fairly straightforward. The technical problem was never how to desalt saline water, but how to produce fresh water from saline water cheaply. (italics added)

Unfortunately, however, the attainment of their price goal ( $\$ 1.00 /$ thousand gallons), which they successfully accomplished, involved substantial technical difficulties which had to be resolved at the demonstration sice. These Lechuical difficulties turned an actual success into a perceived failure ${ }^{4}$ :

By the end of FY65, nine development runs had been completed at the Freeport facility. .... Some of these runs involved several parts each followed by a down period. This pattern of frequent down periods and the consequent failure of the Freeport facility to demonstrate the potential for reliable operation turned out to be significant in a way that probably was not expected. A major promoter of

\footnotetext{
Ibid, Vol. 3, p. G-2.

2 Ibid, p. G-27.

3 Ibid, p. G-27.

4 Ibid, p. G-22.
} 
VTE technology,... explained that potential customers for desalinization facilities have tended to avoid the VTE process because Freeport's track record is interpreted as demonstrating unreliability rather than as being evidence of the systematic attempt to improve the process.

Another hazard which arises when political visibility is too high is the likely imposition of severe time constraints. Table 3-2 shows that of the demonstrations analyzed by the Rand study, the four judged to have been conducted under significant external time constraints were complete failures in both the information and diffusion dimensions.

Probably the most infamous example of such political pressure arose at the Morgantown demonstration of a Personal Rapid 'l'ransit (PRT) system*:

The Morgantown project was badly hampered by the requirement to have a prototype test and inauguration in October 1972 to phase properly with the November presidential election.

The high technical uncertainty existing at the beginning of the program, combined with the stringent time schedule, contributed to the projects' failure...

Thus, we have seen that a pilot plant is essential to the proper technical development of a new technology. It should be built and operated as a small, flexible experimental plant with low political visibility.

The federally funded attempts to skip a pilot and jump straight into expensive, highly visible demonstrations have met with failure. Section III.E addresses the question of what makes a demonstration successful, given that the technology has been well defined.

\section{E. DEMONSTRATIONS AND COMMERCIAL PRODUCTION}

A demonstration has been defined as an experimental plant specifically constructed to lower uncertainty with respect to cost, demand, institutional restrictions and externalities. The necessity of having a well-defined technology has been emphasized. Evidence was presented in previous sections showing that a high political profile and stringent time constraints are significantly

\footnotetext{
* Ibid, p. M-34.
} 
Table 3-2. Time Constraints vs. Project Success

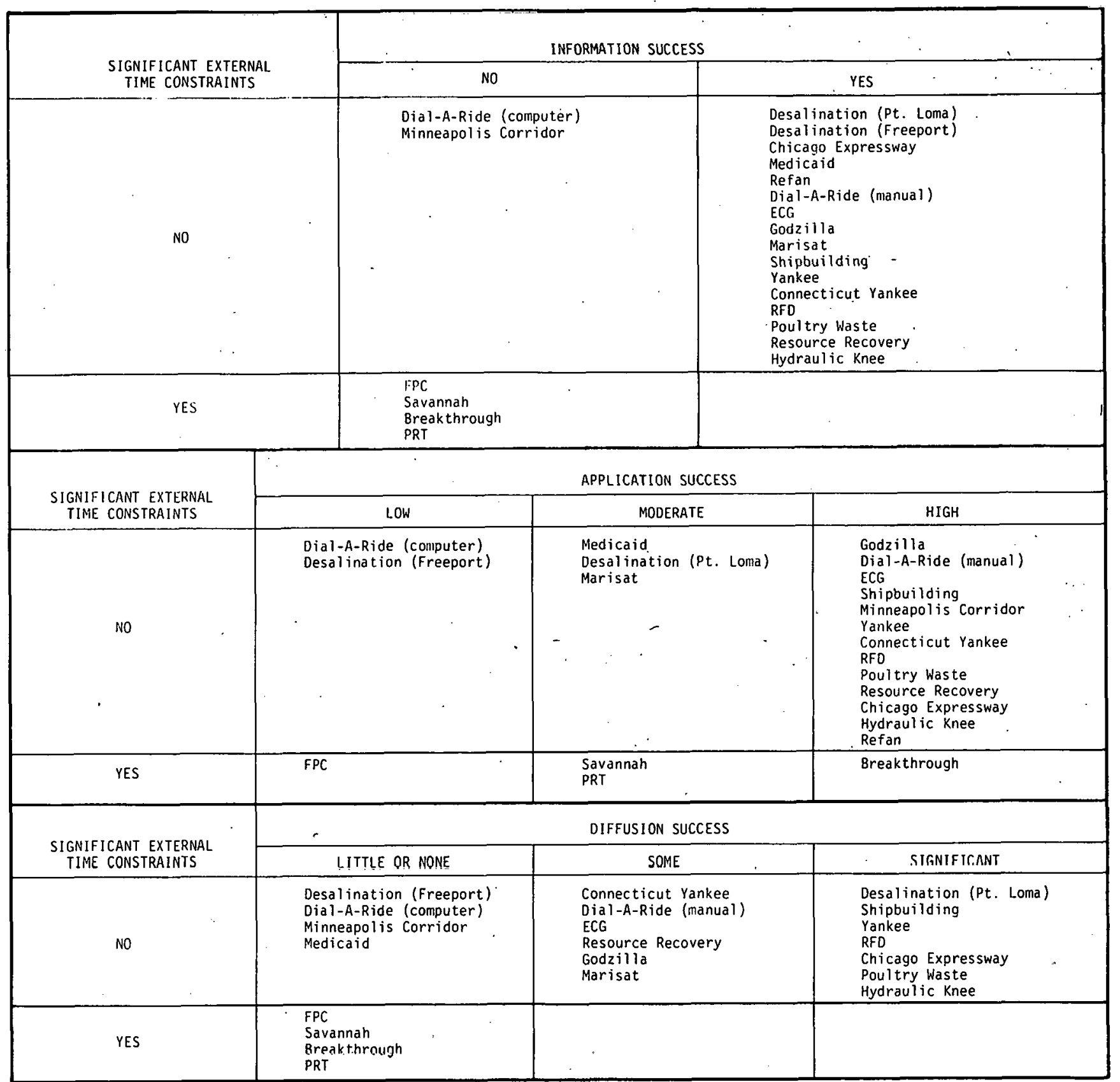

SOURCE: Reprinted from Analysis of Federally Funded Demonstration Projects: Final Report, Walter S. Baer, Leland L. Johnson, and Edward W. Merrow, (Santa Monica: Rand Corporation, April 1976), pp. 54, $182-183$. 
related to demonstrations failures. This section discusses four additional variables which appear to be correlated with demonstration project successes, namely:
(1) Share of federal funding
(2) Initiative for demonstration
(3) Strength of technology delivery system (TDS)
(4) A11 active components of TDS included in demonstration

'The section concludes with a discussion of the usefulness of a commercial scale plant to the attainment of the Photovoltaic Program goals.

As pointed out in the introduction, the primary objective ot the Photovoltaic Program is to promote the production and use of cost-effective photovoltaic devices by private industry. It is clear that in order for private industry to undertake photovoltaic production, there must be a reasonable expectation of a competitive rate of return to such investment. Since a demonstration is the last step in the development of a new technology before commercial production, the level of interest displayed by private industry in a given demonstration is indicative of their assessment of the profit making potential for that technology. That is, a high level of private interest is an indication that the technology is nearly ready for private commercial production. On the other hand, no significant interest by private parties in a demonstration is a danger signal--the technology may be immature, the product too expensive, etc.

Evidence on the level of private interest in past federal demonstrations is presented in Tables 3-3 and 3-4. Here the (1) percentage of federal funding and (2) project origin are plotted against three measures of project success. Even though the correlation ${ }^{1}$ is not overwhelming, successful projects appear more likely to include a high level of private cost-sharing. ${ }^{2}$ The three projects with 100 percent federal funding were total failures at promoting subsequent diffusion of the product. Furthermore, those projects that originated from or were

\footnotetext{
Note that the argument is not one of cause and effect.

${ }^{2}$ Cost sharing as distinguished from risk-sharing. A subsequent paper will discuss in more detail the advantages and disadvantages of various forms of cost and risk sharing.
} 
Table 3-3. Federal Funding.vs. Project Success



*100\% federal funding.

SOURCE: Reprinted from Analysis of Federally Funded Demonstration Projects: Final Report, Walter S. Baer, Leland L. Johnson, and Edward W. Merrow (Santa Monica: Rand Corporation, Apri1 1976) pp. 49, 177-78. 
Table 3-4. Project Initiative vs. Project Success

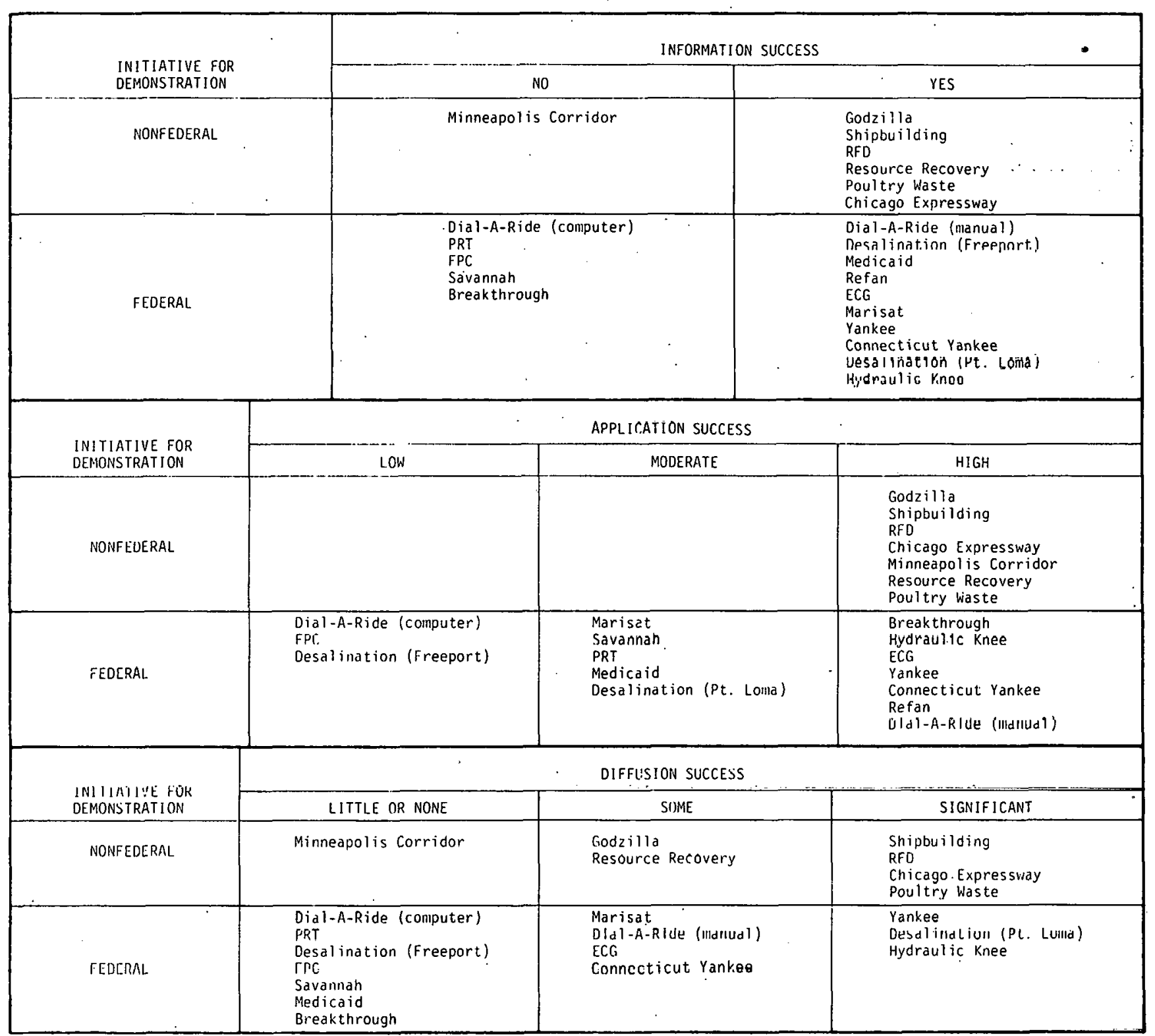

SOURCE: Reprinted from Analysis of Federally Funded Demonstration Projects: Final Report, Walter S. Baer,

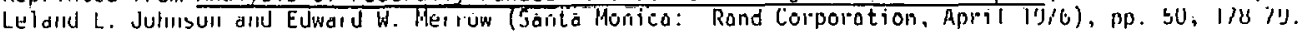


initiated by nonfederal actors enjoyed a significantly higher rate of success in all three dimensions. Thus, those projects which excited a high level of nonfederal participation, either through cost-sharing or project initiation, proved to have a higher probability of success.

A good example of a federal demonstration that failed after ignoring the danger signals arising from the lack of nonfederal participation was the Fish Protein Concentrate (FPC) plant built in Aberdeen, Washington in 1971. The idea of producing a high protein concentrate for human consumption from small, bony fish is intuitively appealing. In 1963, the Secretary of the Interior reoriented the R\&D program on FPC conducted by the Bureau of Commercial Fisheries "toward more rapid commercialization, in support of a U.S. foreign policy goal to expand food supplies in developing nations." 1 Even though the Bureau of Commercial Fisheries' (BCF) research staff did not favor rapid commercialization and wanted to continue research on a wider front, the pressure from Congress was overwhelming: "As one new 'initiative' in the marine resource area the Marine Science Council (MSC) seized upon FPC as a prime candidate for expanding government action. It strongly supported legislation pending before Congress that would specifically authorize federal funds for FPC demonstration plants." 2

The project aroused very little interest in the private sector, however, for two very good reasons: the technology was highly uncertain and the demand for the product was small. Thus ${ }^{3}$ :

The major food processors contacted cited the absence of functional properties as a major barrier to their adoption of FPC, even if it were cost competitive and readily available. A very limited market for non-functional protein exists in soft drinks, pet food and the like. This demand could be met more cheaply by the use of soy protein in one of its many forms. Thus the demonstration produced a product for which no clear domestic market existed.

The plant was permanently closed 15 months after operations began.

The FPC demonstration also illustrates another problem with many federal demonstrations: failure to include all active components of the Technology

\footnotetext{
${ }^{1}$ Ibid, Vol. 2, p. 109.

2 Thid, Vol. 3, p. F 4-5.

$3^{3}$ bid, p. $\mathrm{T}-27$
} 
Delivery System (TDS) in the demonstration. Thus, the food processors were not actively sought after in an effort to shape the project to their needs.

The TDS includes:

(1) the sources of research funding

(2) the R\&D performers

(3) the product manufacturers

(4) the ultimate purchasers and users

Tables 3-5 and 3-6 show that both the strength of the TDS and the extent to which all active components of the TDS are included in the demonstration are important correlates with the success of a demonstration. A TDS is considered strong if previous links have been forged between all members of the anticipated TDS.

\section{Commercial Production}

The final step in the successful introduction of a new technology is, of course, the construction of commercial scale plants. Since the original Project Proposal explicitly called for the encouragement of competitive production by private industry, " there would appear to be no motivation for the LSSA project to consider commercial production. This, however, is not the case. Because of the $500 \mathrm{MW} /$ year peak production goal, LSSA project management is constrained to plan to produce at that rate. Thus, even if a demonstration of the type discussed above would be unnecessary or premature by the 1986 deadline, the project plans to go ahead with a large manufacturing plant or plants for the specific purpose of guaranteeing the output goal.

At best, this plan is inferior, at worst, perverse. Even if we accept the output goal as given, a superior way to guarantee its attainment is through procurements of the type currently carried out by LSSA and called for in the

* See Chapter 1, p. 1. This desire is constantly reiterated. See, for example, the August, 1977 House and Senate versions of the Federal Photovoltaic Utilization Act where the encouragement of private competition is listed as a major goal. 
Table 3-5. Strength of. TDS.vs. Project Success

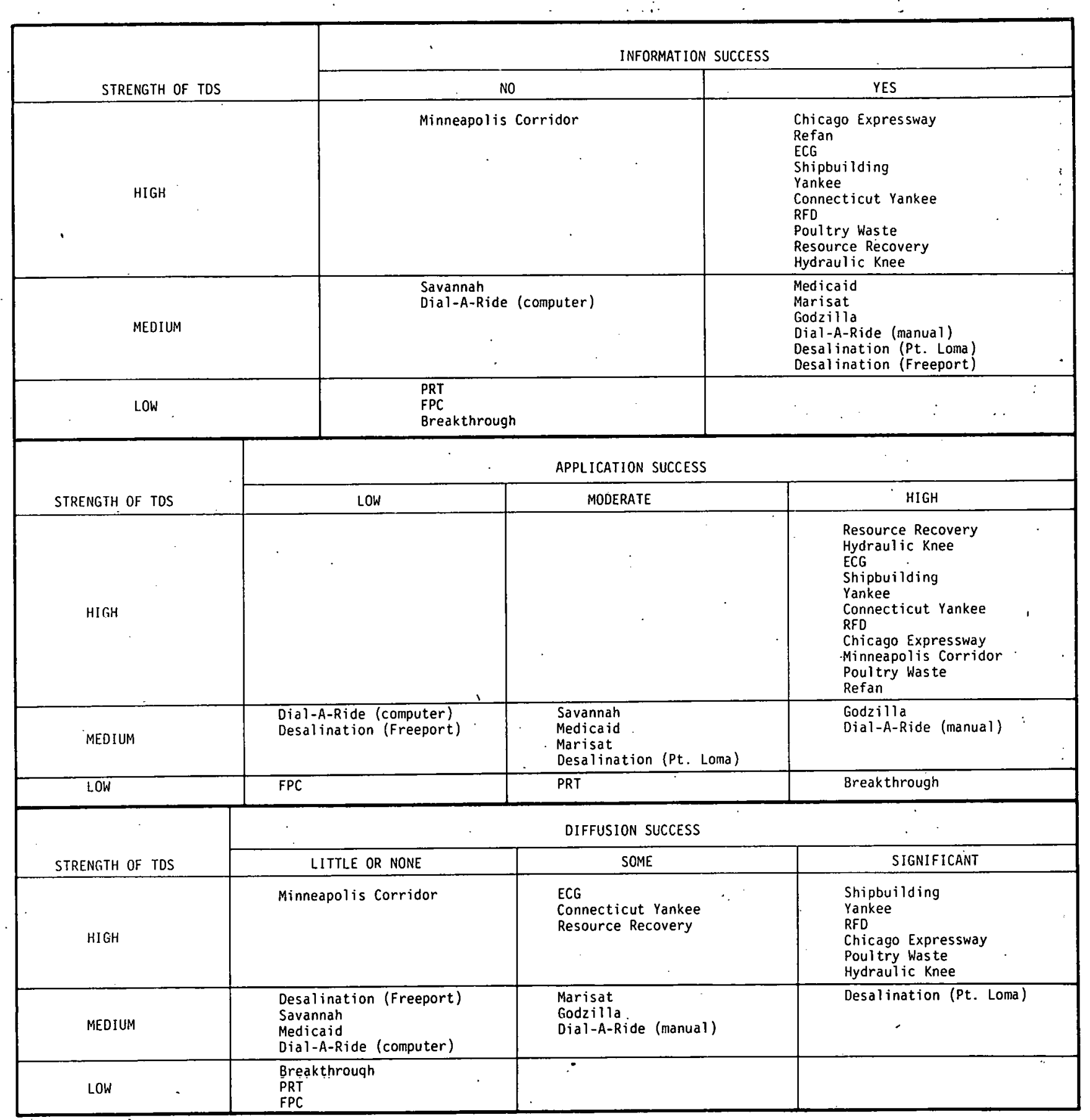

SOURCE: Reprinted from Analysis of Federally Funded Demonstration Projects: Final Report. Waiter $S$, Baer, Leland L. Johnson, Edward W. Merrow (Santa Monica: Rand Corporation, April 1976), pp. 52, 179-80. 
Table 3-6. TDS Components vs. Project Success

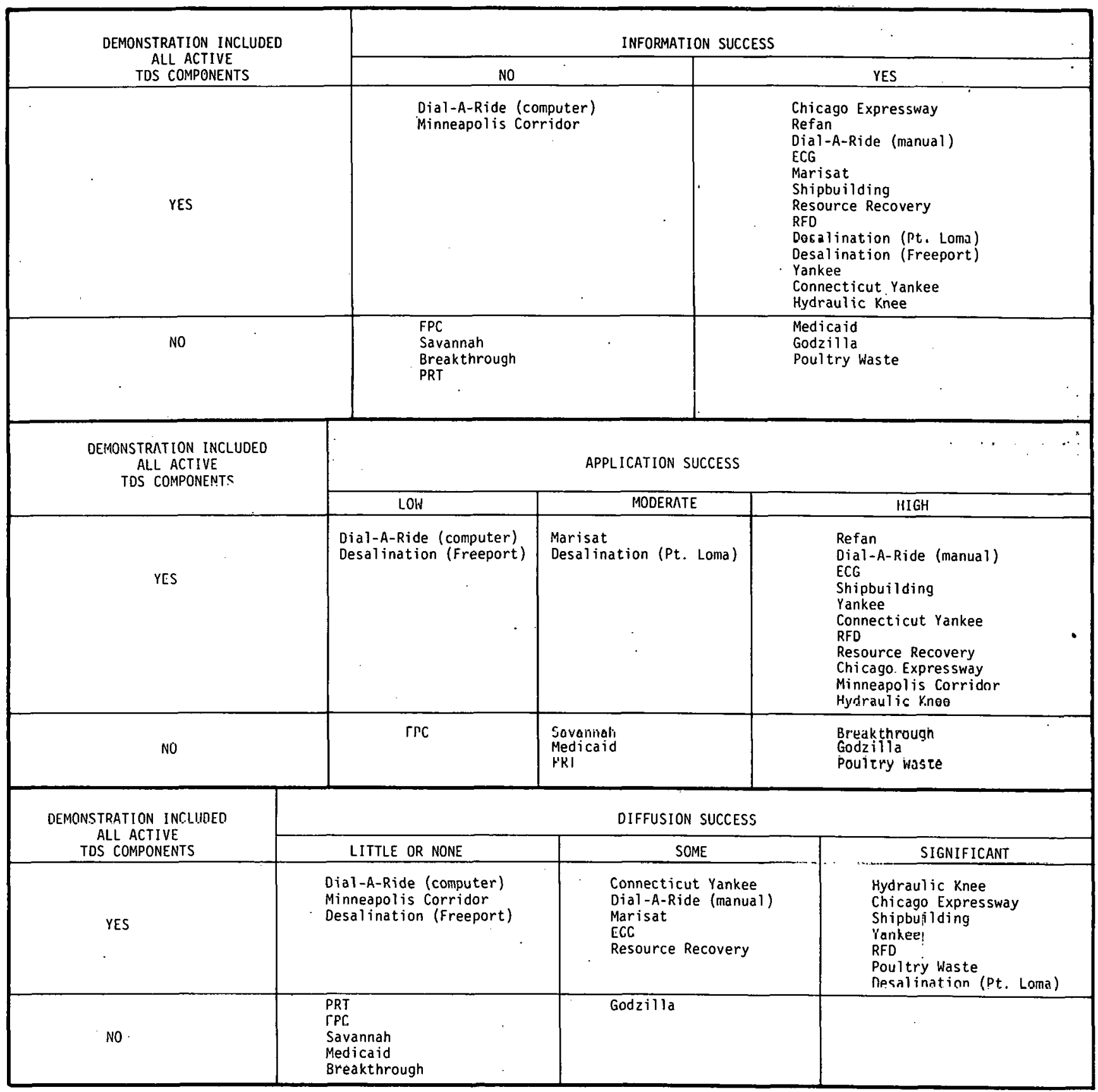

SOURCE: Reprinted from Anaiysis of Federally Funded Demonstration Projects: Final Report, Walter S. Baer, Lel and L. Johnson, Edward W. Merrow (Santa Monica: Rand Corporation, April I976), pp. 53, 181. 
Photovoltaic Utilization Act before Congress. Procurement has several advantages over direct government production:

(1) It promotes competition and efficient production.

(2) Costs of the program are well defined.

(3) Demonstrations can be conducted on their own merits--not confused with commercial production.

Such a procurement program could specify certain technologies, if so desired, to promote their use.

Demand stimulation (procurement), if conducted properly, promotes competition, since the number of potential suppliers is large. Furthermore, efficiency is promoted because only efficient producers will be able to supply at the cheapest prices.

\section{Summary}

This section has delineated four additional variables which are related to successful demonstration projects. Two of these, percent federally financed and origin of project, are indications of the level of private interest in the demonstration. The final two deal with the strength and extent of involvement in the project of the Technology Delivery System. Also, the separate functions of demonstrations and commercial production were emphasized, and it was recommended that the federal government not engage in commercial production.

These conclusions have important implications for the LSSA project. Since photovoltaics in civilian applications is virtually a new industry, the TDS is, by definition, weak. Thus, it is quite important that any large demonstrations include all major components of the system in an attempt to forge links among them. Not only array producers, but ultimate users, including utilities, farmer's co-operatives, etc. must be actively sought after to participate in the demonstration. 
We conclude with a warning emanating from the prestigious Nuclear Energy Policy Study Group (whose membership includes the economists. Kenneth Arrow and Hollis B. Chenery)*:

...Thus there is little value in demonstrating clearly noncompetitive technology unless the demonstration substantially advances the engineering of the technology at a cost commensurate with the value of the advance. If the demonstration takes place before it is economically justified, the government may have to subsidize the program at a high level for a long time after demonstration, and the ultimate product may also be inferior to that which would have resulted from continued development. In addition, premature commitment to expensive demonstration programe can distort the balance of the federal energy program. We believe that the government must exercise greater care in the future before moving into the very costly phases of the development. chain.

The Nuclear Energy Policy Study Group, Nuclear Power Issues and Choices (Cambridge, Mass.: Ballinger Publishing Company, 1977), p. 13. 


\section{SECTION IV}

SUMMARY AND CONCLUSIONS

This document has attempted to anticipate some problems which may arise as the LSSA Project attempts to transfer to the private sector the new technologies developed within the Project.

The key roles played by product price and effective product demand at that price were emphasized. The analysis went on to consider another potential problem--the adoption of new technologies by photovoltaic suppliers. Innovation and diffusion were defined and the determinants of the optimum rate of diffusion were discussed. No impediments to the rapid diffusion of photovoltaic technology were expected from market structure, venture capital availability or information flow. impediments.

However, the inconsistency found in current program plans to encourage a highly capital intense, automated technology in the presence of rapid technological change was stressed. It was concluded that no push for final industrialization should be attempted until the technology was fully developed and stable. Other possible impediments to rapid diffusion could arise if the project attempts to subsidize or compete with private commercial production. It was recommended that no commercial production of photovoltaic arrays be undertaken by the federal.government.

Thus, other than artificial impediments flowing from the conduct of the program itself, no barriers to the rapid adoption by private producers is anticipated given attainment. of the product price and sufficient effective demand at that price. This conclusion was supported by evidence from the semiconductor, petroleum and iron and steel industries. Further, it was recommended that any subsidy to encourage the use of photovoltaics be applied at the demand side to avoid any injury to the expected competitive market structure of the supply industry.

In light of these conclusions, the $500 \mathrm{MW}$ peak/year quantity goal was reexamined. Three possible motives for the goal were identified. It was shown that either the goal should be completely dropped or moved to a purely passive 
role at Program Headquarters to function as an arbiter on the success or failure of the entire program. It was argued that direct government production to satisfy the goal would not be useful.

Section III discussed the relative merits of various forms of experimental production plants to the LSSA Project and Photovoltaic Program. The functional distinction between pilot plants (technological research and development) and demonstration plants (cost, environmental, reliability, regulatory considerations) was emphasized. The different types of information each plant is designed to compile were pointed out and the improper distinction between such plants on the basis of size was discussed. Thus, it was recommended that pilot plants be constructed whenever they would facilitate the R\&D phases of the program, but that demonstrations be delayed until the technology is well in hand.

Evidence from a voluminous study, Analysis of Federally Funded Demonstration Projects, by Rand Corporation and John Tilton's book International Diffusion of Technology: The Case of Semiconductors was used to support the analysis throughout. 


\section{BIBLIOGRAPHY}

1. Adams, Walter and Joel Dirlam, "Big Steel, Invention and Innovation," The Quarterly Journal of Economics; May 1966.

2. Ault, David, "The Continued Deterioration of the Competitive Ability of the U.S. Steel Industry: The Development of Continuous Casting," Western Economic Journal, March 1973.

3. Baer, Walter S., Leland L. Johnson, and Edward W. Merrow, Analysis of Federally Funded Demonstration Projects, Three Volumes: Executive Summary (R-1925-DOC); Final Report (R-1926-DOC); Case Studies (R-1927-DOC). The Rand Corporation, Santa Monica, CA, April 1976.

4. Carter, C. F. and B. R. Williams, Industry and Technical Progress. Oxford University Press, London, 1957.

5. Enos, John, "Invention and Innovation in the Petroleum Refining Industry," in The Rate and Direction of Inventive Activity, National Bureau of Economic Research, Princeton Univ. Press, Princeton, 1962.

6. First Annual Report, LSSA Project, ERDA/JPL-1012-76/5, August 1976, JPL • publication.

7. Gates, Bil1. "Prospects for Innovation and Diffusion of Photovoltaic Technology," August 1977, unpublished JPL study.

8. Jordon, Donald G., Kirk-Othmer Encyclopedia of Chemical Technology, Voluline 15, Second Edition. Interscience Publishers, New York, 1968.

9. Lee, Tom, "Sequential Pilot-Demonstration-Commercial Strategy and Its Relation to LSSA's Industrialization Plans," August 1977, unpublished JPL study.

10. "LSSA's Efforts Toward Effective Technology Transfer," JPL unpublished Interoffice memo, anonymous, January' 1978.

11. Mansfield, Edwin S., "Determinants of the Speed of Application of New Technology," in B.R. Williams, Science and Technology in Economic Growth. John Wiley and Sons, New York, 1973. 
12. Mansfield, Edwin S.. Industrial Research and Technological Innovation. W. W. Norton and Co., New York, 1971.'

13. The Nuclear Energy Policy Study Group, Nuclear Power Issues and Choices. Ballinger Publishing Co., Cambridge, MA, 1977.

14. Photovoltaic Program Planning Group. Commercialization and Industrialization of Photovoltaics: Draft Plan, July 1977, Energy Research and Development Administration, Washington, D.C.

15. Photovoltaic Program Planning Group, National Solar Photovoltaic Program Plan, unpublished document, July 1977.

16. Policy Study Group, Massachusetts Institute of Technology Energy Laboratory, Government Support for the Commercialization of New Energy Technologies. Energy Laboratory Report MIT-EL 76-009, Cambridge, MA, November 1976.

17. Roberts, E. B., "Entrepreneurship and Technology,". in Gruber and Marques, Factors in the Transfer of Technology. MIT Press, Cambridge, MA, 1969.

18. Robinson, Joan. The Accumulation of Capital. The MacMillan Press, Ltd., London, 1956.

19. Salter, William E., Productivity and Technological Change. Cambridge Iniversity Press, 1966.

20. Tilton, John E., International Diffusion of Technology: The. Case of Semiconductors. The Brookings Institution, Washington, D.C., 1971.

21. United States Congress, Federal Photovoltaic Utilization ACt, U.S. Senate bill, pending.

22. United States Congress, studies prepared for the use of the JulnL Ecullumic Committee, U.S. Economic Growth from 1976 to 1986: Prospects, Problems, ard Patterns. Technological Change, Vol. 9, Government Printing Office, Washington, D.C., January 1977. 